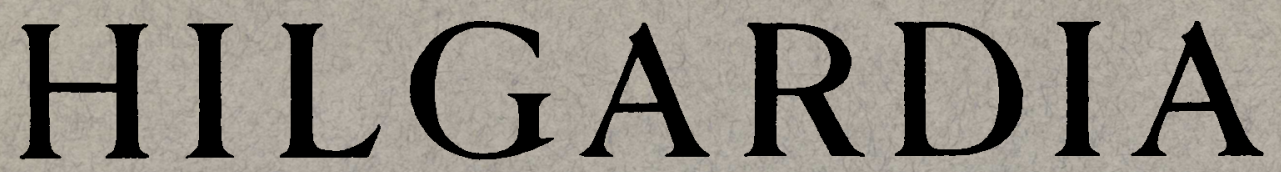

A Journal of Agricultural Science Published by the California Agricultural Experiment Station

\title{
ORNAMENTAL FLOWERING PLANTS EXPERIMENTALLY INFECTED WITH CURLY TOP
} JULIUS H. FREITAG AND HENRY H. P. SEVERIN

NEGATIVE EVIDENCE ON MULTIPLICATION OF CURLY-TOP VIRUS IN THE BEET LEAFHOPPER, EUTETTIX TENELLUS

JULIUS H. FREITAG 


\title{
H I L G A R D I A
}

A Journal of Agricultural Science Published by

the California Agricultural Experiment Station

-Vol. 10

NOVEMBER, 1936

No. 9

\section{ORNAMENTAL FLOWERING PLANTS EXPERIMENTALLY INFECTED WITH CURLY TOP}

\author{
JULIUS H. FREITAG ${ }^{2}$ AND HENRY H. P. SEVERIN ${ }^{3}$
}

(Contribution from the Division of Entomology and Parasitology, College of Agriculture, University of California, coöperating with the United States Department of Agriculture Bureau of Entomology.)

\section{INTRODUCTION}

Several investigators have recorded the experimental transmission of virus diseases of plants to a large number of species in different genera of many families. A review of the literature on the host range of certain virus diseases shows an extensive host range as determined by experimental infection, but the reported natural host range is often limited, as illustrated in table 1.

The natural infection of ornamental flowering plants with curly top has already been reported in a previous paper. ${ }^{(27) 4} \mathrm{~A}$ list of the plants experimentally infected, but without details of the experiments or description of the symptoms, was published in the Plant Disease Reporter. ${ }^{(i)}$ The details and results of the experiments performed to experimentally infect ornamental flowering plants with curly top are given in the present paper. No intensive investigations have been conducted to determine which plants are resistant or immune to curly top; only plants experimentally infected with the disease are reported in this paper. The symptoms on the susceptible host plants are briefly described. The longevity of the last living male and female beet leafhopper, Eutettix tenellus (Baker), was ascertained on inoculated plants and a record was kept of all plants on which the leafhopper completed its life cycle.

\footnotetext{
${ }^{1}$ Received for publication February 14, 1936.

${ }^{2}$ Junior Entomologist in the Experiment Station.

${ }^{3}$ Associate Entomologist in the Experiment Station.

"Superscript numbers in parentheses refer to "Literature Cited" at the end of the paper.
} 


\section{ME'THODS OF EXPERIMENTALLY INFECTING PLANTS WITH CURLY TOP}

The methods used in the transmission of curly top to ornamental flowering plants were somewhat similar to those described in the experimental infection of economic plants and weeds reported in an earlier contribution. ${ }^{(28)}$ The ornamental flowering plants were grown from seeds in the

TABLE 1

Host Ranges of Some Plant Virus Diseases as Determined by Natural AND EXPERIMENTAL INFECTION

\begin{tabular}{|c|c|c|c|c|c|c|c|c|}
\hline \multirow{2}{*}{ Virus disease } & \multirow{2}{*}{ Authority* } & \multirow{2}{*}{ Locality } & \multicolumn{3}{|c|}{$\begin{array}{l}\text { Plants experimentally } \\
\text { infected }\end{array}$} & \multicolumn{3}{|c|}{$\begin{array}{c}\text { Plants naturally } \\
\text { infected }\end{array}$} \\
\hline & & & Species & Genera & Families & Species & Genera & Families \\
\hline $\begin{array}{l}\text { Sugar beet } \\
\text { curly top }\end{array}$ & $\left\{\begin{array}{l}\text { Severin and co- } \\
\text { workers }(7,14,15 \\
17,18,19,20,25 \\
26,27,28) \\
\text { Carsner }(6)\end{array}\right.$ & $\begin{array}{l}\text { California } \\
\text { California }\end{array}$ & $\begin{array}{r}194 \\
14\end{array}$ & $\begin{array}{r}122 \\
13\end{array}$ & $\begin{array}{r}40 \\
8\end{array}$ & $\begin{array}{l}75 \\
\cdots\end{array}$ & $\begin{array}{l}48 \\
\cdots\end{array}$ & $\begin{array}{l}18 \\
. .\end{array}$ \\
\hline Aster yellows & $\left\{\begin{array}{l}\text { Kunkel }(11,12) \\
\text { Severin }(21,24,26,\end{array}\right.$ & New York & 170 & 150 & 38 & 9 & 9 & 4 \\
\hline & (27) & California & 7 & 5 & 2 & 14 & 13 & 6 \\
\hline $\begin{array}{l}\text { Southern celery } \\
\text { mosaic }\end{array}$ & Wellman $(33,34)$ & Florida & 81 & 59 & 23 & 42 & 35 & 17 \\
\hline $\begin{array}{l}\text { Tobacco ring- } \\
\text { spot }\end{array}$ & $\begin{array}{l}\text { Wingard }(35,36) \\
\text { Bald and Samuel }\end{array}$ & Virginia & 62 & 38 & 17 & 11 & 9 & 3 \\
\hline $\begin{array}{l}\text { Tomato spotted } \\
\text { wilt }\end{array}$ & $\left\{\begin{array}{l}(5) \\
\text { Smith }(29,30,31) \\
\text { Gardner and co- } \\
\text { workers }(8,9,32)\end{array}\right.$ & $\begin{array}{l}\text { Australia } \\
\text { England } \\
\text { California }\end{array}$ & $\begin{array}{l}35 \\
28 \\
30\end{array}$ & $\begin{array}{l}15 \\
13 \\
24\end{array}$ & $\begin{array}{r}4 \\
4 \\
19\end{array}$ & $\begin{array}{r}4 \\
4 \\
31\end{array}$ & $\begin{array}{r}4 \\
4 \\
31\end{array}$ & $\begin{array}{r}4 \\
4 \\
17\end{array}$ \\
\hline Tobacco mosaic & Grant (10) & Wisconsin & 29 & 24 & 14 & . & .. & .. \\
\hline $\begin{array}{l}\text { Tomato bunchy } \\
\text { top }\end{array}$ & McClean (13) & South Africa & 15 & 8 & 2 & .. & .. & $\ldots$ \\
\hline
\end{tabular}

* Numbers in parentheses refer to numbers in list of "Literature Cited" at the end of this paper.

greenhouse and were fumigated with Nico-Fume tobacco-paper insecticide prior to using. Each plant was enclosed in a cage and inoculated with curly top by either infective male or female beet leafhoppers which had completed their nymphal stages on beets in an advanced stage of the disease. The number of insects used varied from 5 to 20 , according to the size of the plants. When the longevity of the adults was short, presumably because of unfavorable food, the plants were repeatedly inoculated by different lots of infective insects. 
The plants were exposed to the infective leafhoppers until symptoms of eurly top developed, which usually required about two weeks ; if no symptoms appeared, the insects were kept on the plants for a period of 6 weeks. After inoculation the cage containing the infective specimens was removed, and care was taken to see that the plant was free from all insects.

Healthy plants of each species or variety were exposed to noninfective beet leafhoppers as a check, and as a further check, healthy plants were grown in cages free from insects.

No species or variety of ornamental flowering plant inoculated with curly top was considered to be infected with the disease on the basis of symptoms, unless the virus was recovered by previously noninfective male leafhoppers or nymphs and transferred to sugar beets. From 2 to 10 plants of each species or variety were inoculated, as indicated in table 2. Small plants were ordinarily used, but sometimes plants susceptible to curly top would die before the virus could be transferred to sugar beets, and hence larger plants were inoculated.

In one method of recovering the virus, the inoculated plants were exposed to previously noninfective male leafhoppers enclosed in a cage for a period of 2 or 3 days, or longer if the food material was favorable. (In order to avoid egg deposition, females were not used in this type of recovery tests.) The insects were then transferred from the inoculated plant to two healthy beet seedlings, each enclosed in a cage. Two beet seedlings were used in each test because occasionally a seedling is killed by damping-off. The leafhoppers were confined in cages enclosing the beet seedlings for a period of 5 to 7 days, and then the cages containing the leafhoppers were removed.

In another method of recovering the virus, nymphs which hatched from eggs deposited in favorable food plants by infective females used to inoculate the plants, were transferred to beet seedlings. It has been established ${ }^{(16,23)}$ that nymphs which hatch from eggs deposited by infective females are not able to transmit curly top unless the nymphs have previously fed on a diseased plant.

The inoculated beets were fumigated with Nico-Fume tobacco-paper insecticide and were kept within insect-proof cages for a period of 3 months, if symptoms of curly top did not develop within the usual period of 1 to 2 weeks. If the beets developed curly top, it is evident that the inoculated ornamental flowering plant had been infected with the disease. 







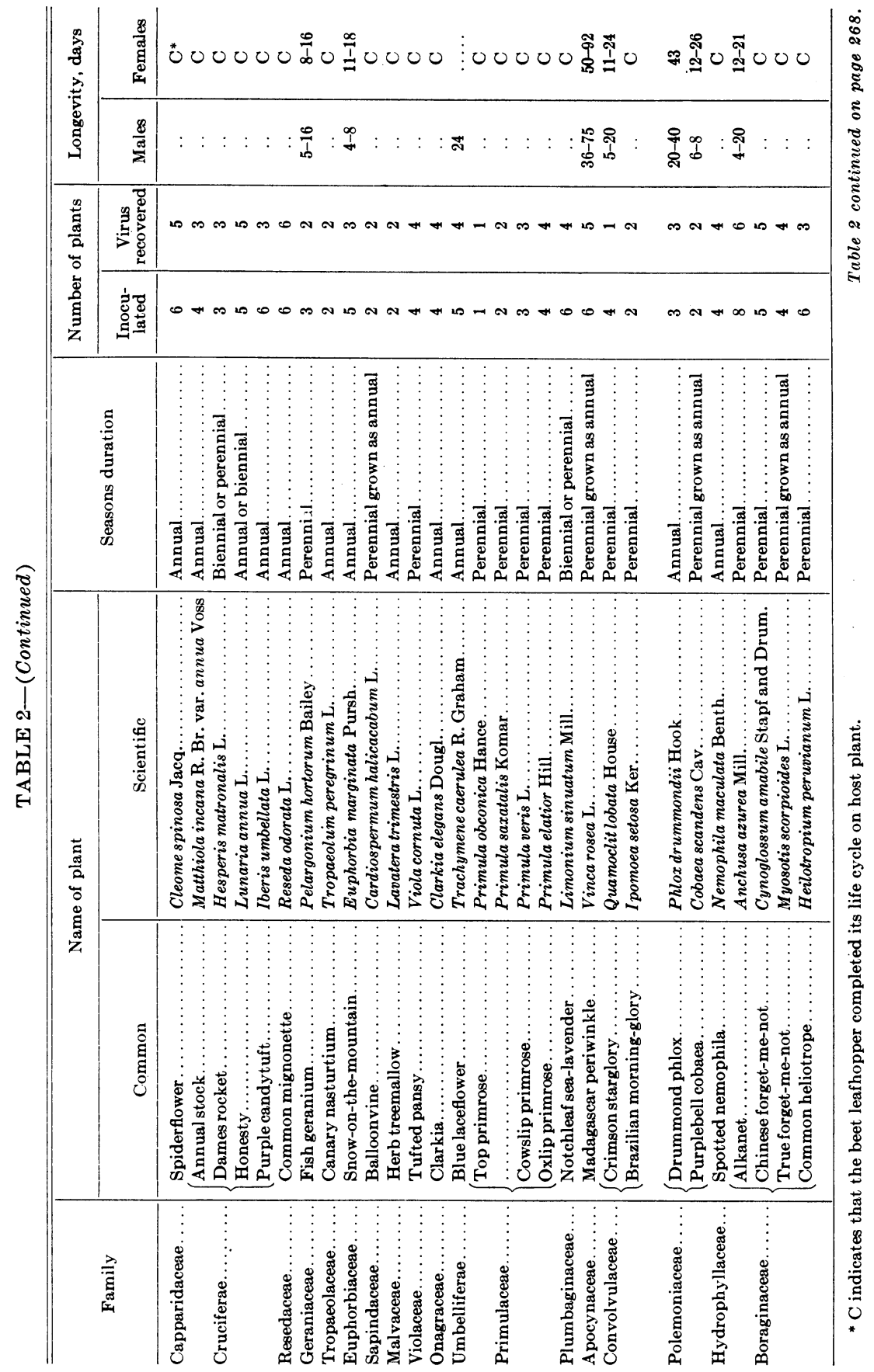




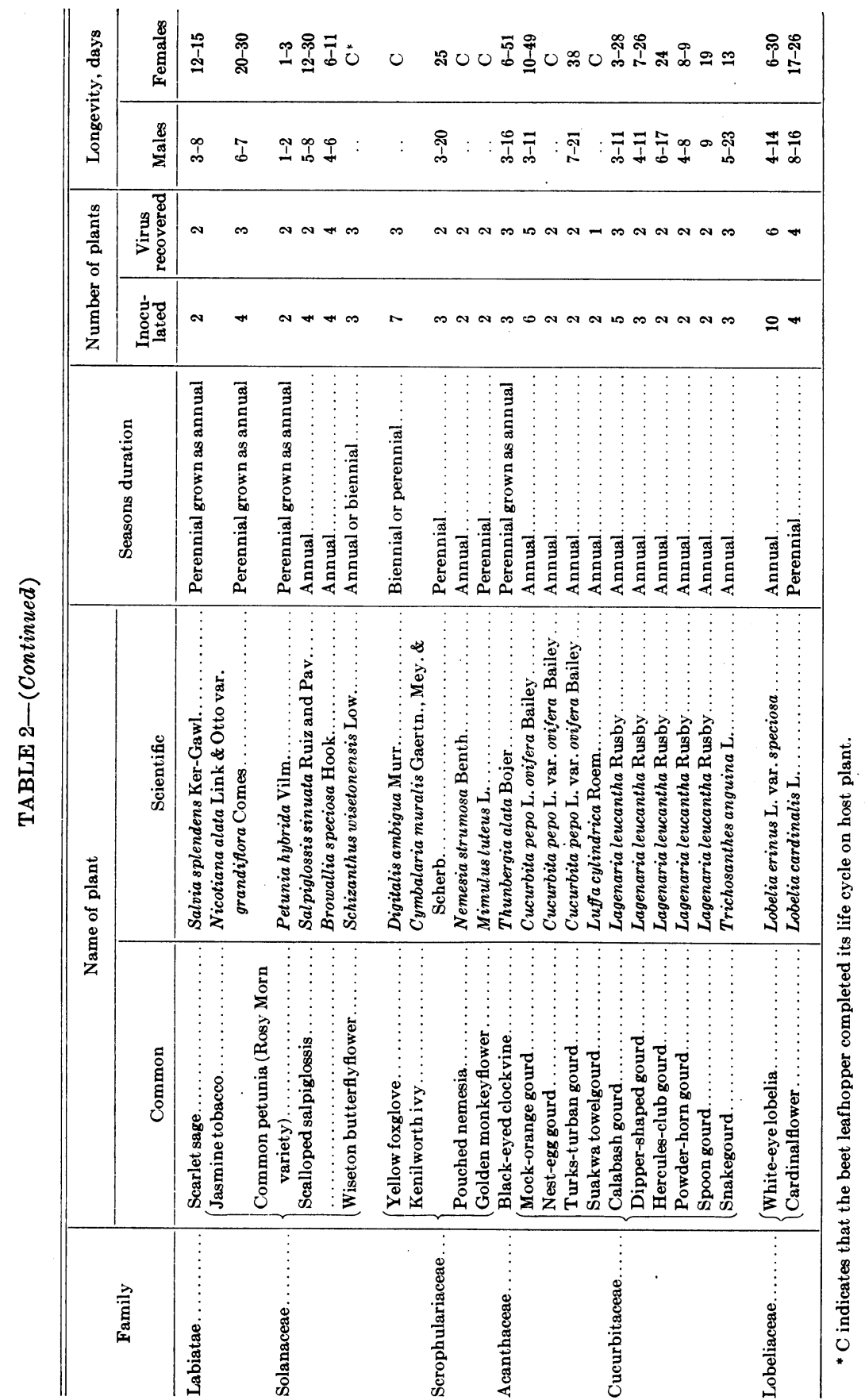




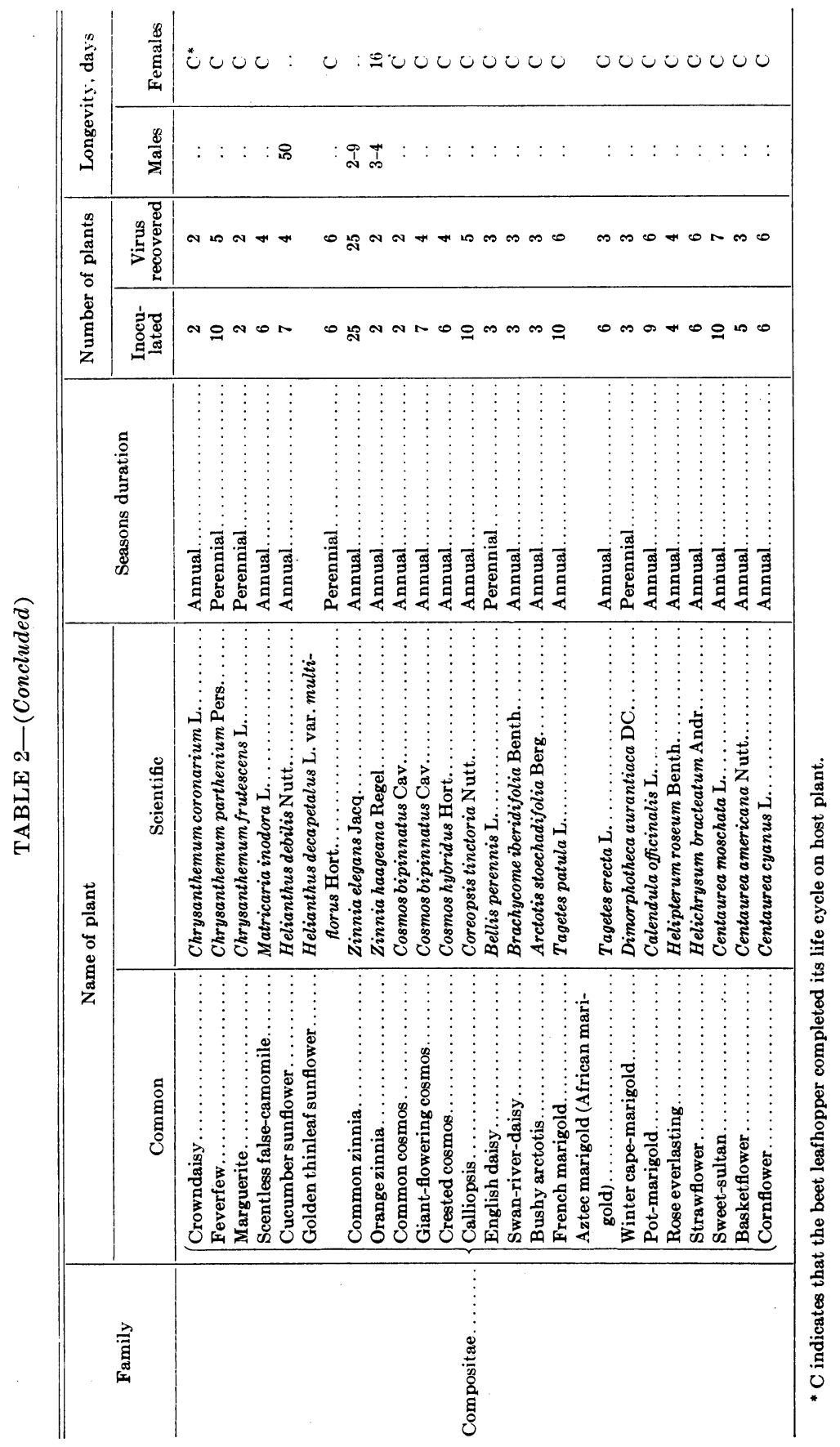




\section{HOST RANGE OF CURLY TOP AMONG ORNAMENTAL FLOWERING PLANTS}

The number of ornamental flowering plants inoculated with curly top and the number of infected plants from which the virus was recovered by previously noninfective beet leafhoppers and transferred to beet seedlings is shown in table 2 . The host range of curly top among ornamental flowering plants includes 92 species in 73 genera belonging to 33 families.

Many species of ornamental flowering plants repeatedly inoculated by different lots of infective beet leafhoppers showed no foliage symptoms and the virus was not recovered from such plants. These plants apparently are either immune or resistant to curly top and are not listed in table 2.

\section{SYMPTOMS OF CURLY TOP}

Environmental conditions are important factors influencing the expression of curly-top symptoms. High humidity and high temperatures with a range of $70^{\circ}$ to $110^{\circ} \mathrm{F}$ were maintained in the greenhouse during the summer months. Certain species of plants which displayed no outstanding symptoms of curly top might have developed them under different humidity and temperatures.

Ornamental flowering plants infected with curly top show a variation in symptoms. Many plants develop some of the symptoms developed by the sugar beet as described in a previous paper. ${ }^{(22)}$ Other infected plants such as Madagascar periwinkle (Vinca rosea), common heliotrope (Heliotropium peruvianum), and purple candytuft (Iberis umbellata) did not develop symptoms. Either such species are symptomless carriers of the disease or the symptoms are entirely masked under greenhouse conditions.

The effect of the disease on the flowers of many species was not studied in detail. Young plants infected with curly top frequently produce no flowers as they mature. Older plants infected before blooming often develop dwarfed, malformed, and fewer flowers than healthy plants. Some species of infected plants produce normal flowers.

A brief description of symptoms on the individual species follows. These symptoms are described in many instances from young infected plants. Such symptoms are often more pronounced than those shown by plants infected at a later stage of development. Plants grown from seeds in the greenhouse and enclosed in cages often assume a spindling habit, and the symptoms of curly top on such plants are often different from those shown by plants naturally infected in the field. 


\section{Moraceae, Mulberry Family}

On Japanese hop (Humulus japonicus) infected with curly top no symptoms were apparent.

\section{Chenopodiaceae, Goosefoot or Saltbush Family}

Common summer cypress (Kochia trichophylla) infected with curly top showed severe foliage symptoms and developed secondary shoots from the axils of the leaves. The terminal leaves of the branches and axillary shoots were dwarfed and twisted, sometimes in a spiral. The margin and midrib of the leaves were sinuous, with knot-like swellings on the latter. The leaves showed blister-like elevations on the lower surface and cleared veinlets.

\section{Amaranthaceae, Amaranth Family}

Amaranthus aurora infected with curly top was stunted, having shortened internodes and secondary shoots arising from the axils of the leaves. The terminal leaves of the main and secondary shoots were dwarfed, with the outer margin rolled inward, and with the petioles often bent downward or twisted (plate 1, $A$ ). The lateral veins were sinuous, and developed knot-like swellings, and the veinlets were transparent.

On Josephs-coat (Amaranthus gangeticus) the symptoms of curly top were somewhat similar to those described on $A$. aurora. The leaf tissue between the protruding lateral veins was sunken in such a manner that the leaf resembled a corkscrew (plate $1, B$ ).

On love-lies-bleeding (Amaranthus caudatus) the symptoms of curly top were similar to those described on A. aurora. Infected plants kept out of doors developed a compact mass of dwarfed, curled leaves at the apexes of the stems.

Feather cockscomb (Celosia argentea) infected with curly top was stunted and developed numerous axillary shoots. The pluming heads were dwarfed and had few branches (fig. 1), which were dark red or brownish red in color instead of the normal scarlet.

On common globe-amaranth (Gomphrena globosa) the symptoms of curly top were similar to those described on Amaranthus aurora.

\section{Nyctaginaceae, Four-o'Clock Family}

Common four-o'clock (Mirabilis jalapa) infected with curly top was stunted and developed dark, dull green leaves on the axillary shoots. The youngest leaves were cupped outward and the veinlets were transparent. 


\section{Portulacaceae, Purslane Family}

Common portulaca (Portulaca grandiflora) infected with curly top was stunted and chlorotic, bearing numerous axillary dwarfed leaves.

Common rockpurslane (Calandrinia grandiflora) infected with curly top was stunted, the older leaves cupped outward, and the younger dwarfed leaves formed a compact mass of curled leaves (fig. 2).

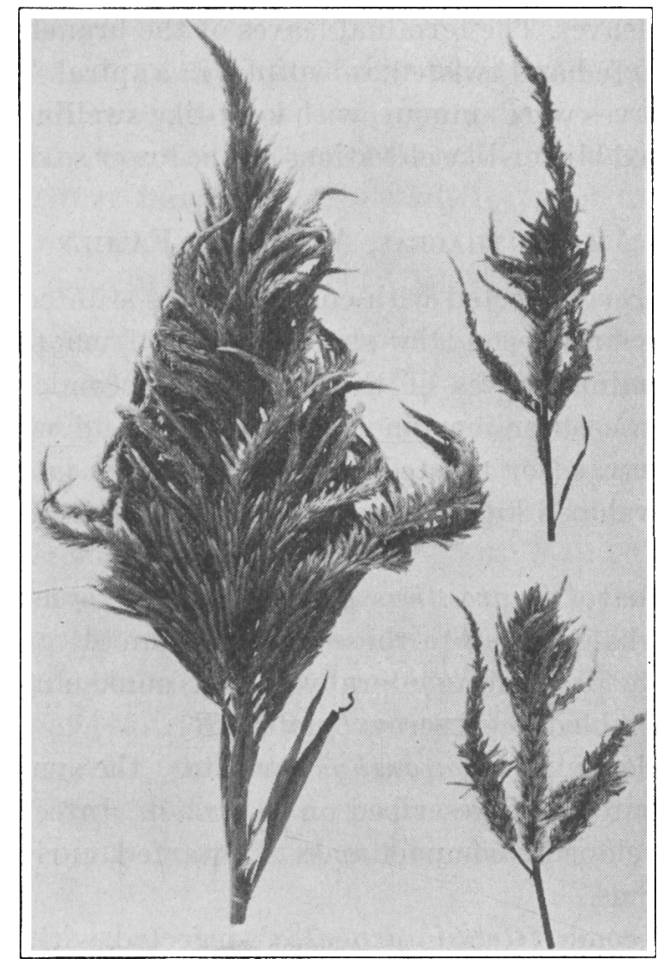

Fig. 1.-Feather cockscomb (Celosia argentea): left, conical pluming head from healthy plant; right, dwarfed pluming heads from two plants infected with curly top, showing reduction in number and size of branches.

\section{Caryophyllaceae, Pink Family}

Sweet william (Dianthus barbatus) infected with curly top was stunted, and had shortened internodes. The younger leaves at the apexes of the shoots were dwarfed, yellow, and curled, while the somewhat older leaves were often twisted (fig. 3 ) and had sinuous veins, cleared veinlets, and protuberances on the lower surface. 


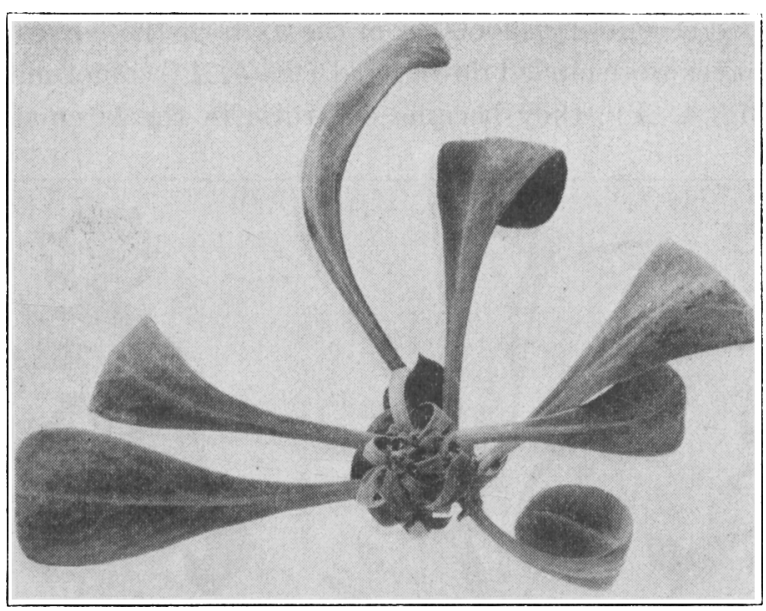

Fig. 2.-Common rockpurslane (Calandrinia grandiflora) infected with curly top, showing stunted plant with the older leaves cupped outward and the younger leaves forming a compact mass of curled leaves.

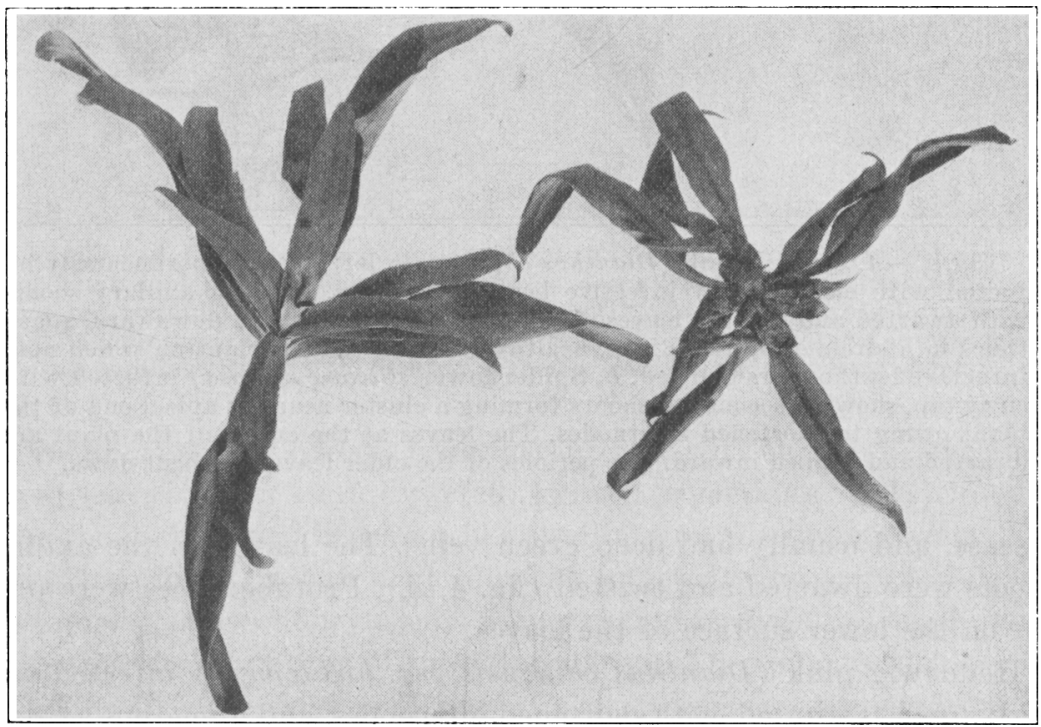

Fig. 3.-Sweet william (Dianthus barbatus): left, tip of a shoot from a healthy plant; right, apical end of a shoot from a plant infected with curly top, showing dwarfed, curled, younger leaves, and twisted older leaves. 
Chinese pink (Dianthus chinensis) infected with curly top was stunted and developed secondary shoots from the axils of the leaves (fig. 4, A). The older leaves were curled downward (fig. 5, $A$ ), sometimes in a circle or spiral (fig. $4, A$ ); they became chlorotic in the later stages of the

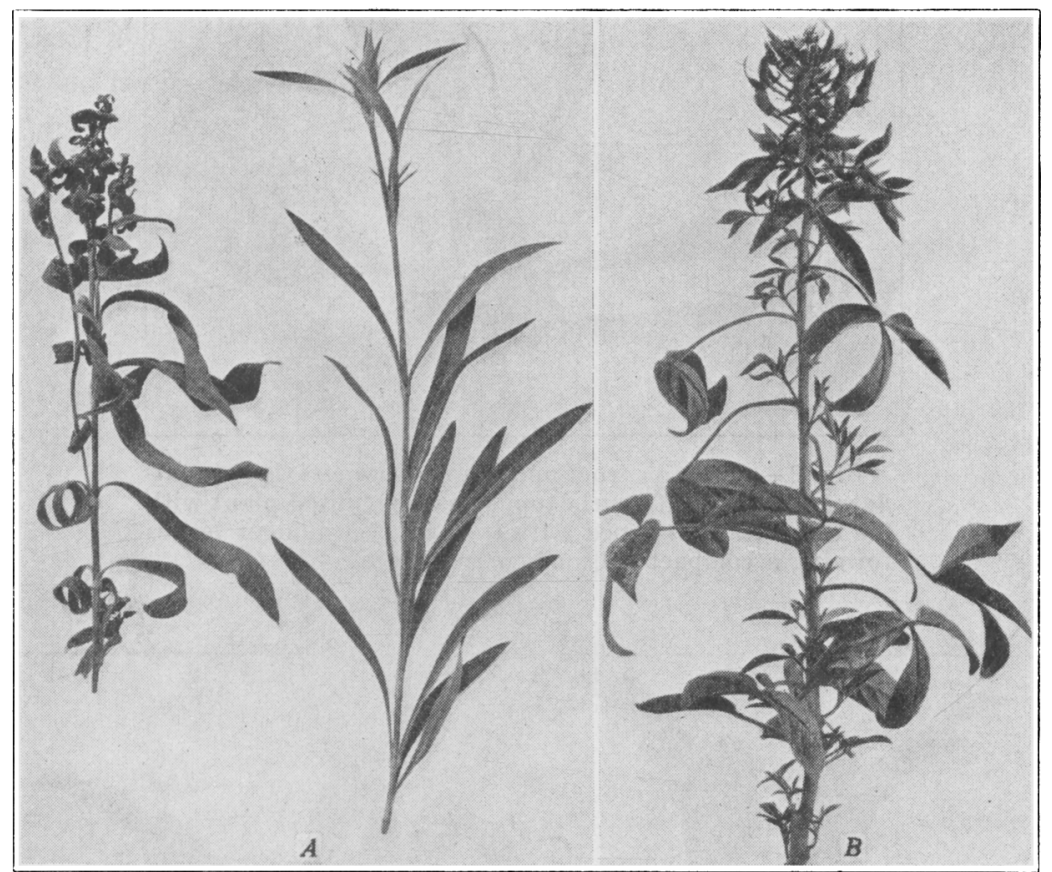

Fig. 4.-A, Chinese pink (Dianthus chinensis) : left, plant experimentally infected with curly top by infective beet leafhoppers, showing axillary shoots with dwarfed and twisted leaves. The older leaves are curled downward, sometimes in a circle or spiral. Right, healthy check or control plant on which noninfective leafhoppers had fed. $B$, Spiderflower (Cleome spinosa) infected with curly top, showing secondary shoots forming a cluster near the apical end of the plant owing to shortened internodes. The leaves at the crown of the plant are dwarfed and cupped inward. The petioles of the older leaves are bent down.

disease, and usually had deep green veins. The leaves on the axillary shoots were dwarfed and twisted (fig. $4, A$ ). Protuberances were present on the lower surface of the leaves.

Heddewig pink (Dianthus chinensis var. heddewigii) infected with curly top was stunted, with shortened internodes, and numerous axillary shoots. The leaves were curled downward and were often twisted. Protuberances resembling tiny warts were present on the lower surface of the leaves with pits or depressions on the upper surface of the leaves corresponding to the position of the small elevations on the under side. 
On grass pink (Dianthus plumarius) the symptoms of curly top were similar to those described for Chinese pink (D. chinensis).

Carnation (Dianthus caryophyllus) developed leaves at the apex of infected plants and on the secondary shoots which were chlorotic and curled downward.

Babysbreath (Gypsophila paniculata) infected with curly top showed no symptom of the disease under greenhouse conditions.

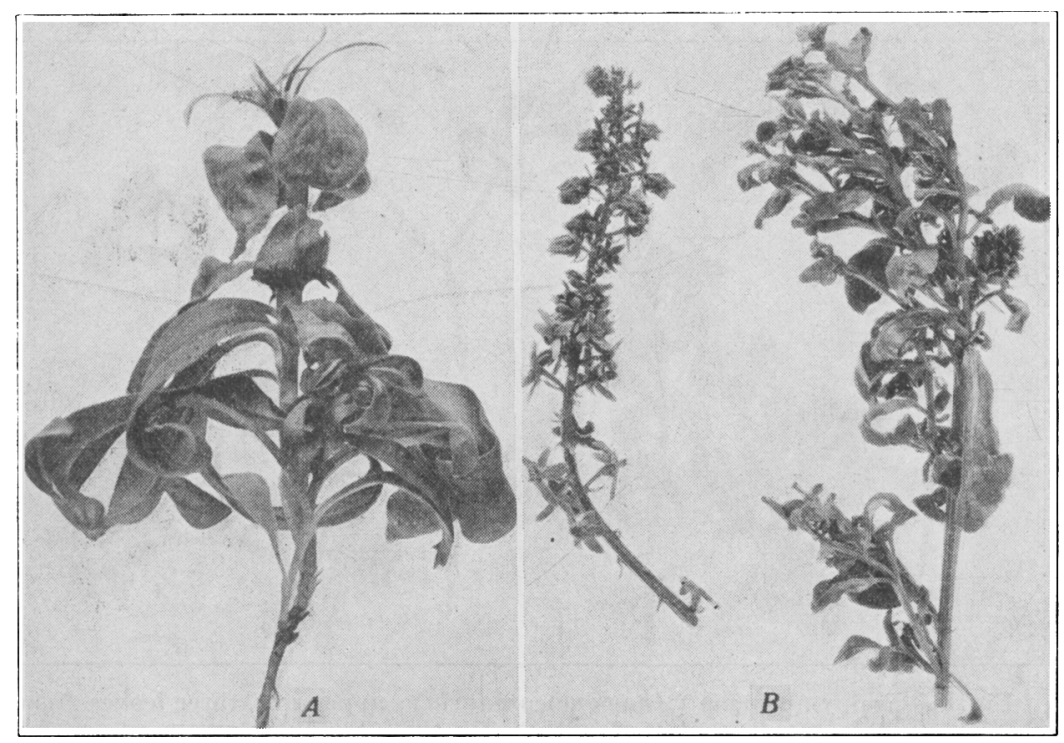

Fig. 5.-A, Chinese pink (Dianthus chinensis) infected with curly top, showing stunted plant with older leaves curled downward and with dwarfed, filamentous, terminal leaves. $B$, Common mignonette (Reseda odorata) : left, floral inflorescence from a plant infected with curly top, showing flowers with sepals and no corollas; right, stem from an infected plant showing axillary shoots.

Drooping catchfly (Silene pendula) infected with curly top developed young leaves which were dwarfed, twisted, sometimes folded inward along the midrib, and had knot-like swellings on the sinuous veins.

Maltese cross (Lychnis chalcedonica) infected with curly top developed numerous secondary shoots with dwarfed terminal leaves showing an inward curl or rolling of the outer margin. The veins were distorted with knot-like swellings, and wart-like protuberances occurred on the lower surface of the leaves. The veinlets on the youngest leaves were cleared.

On Haage campion (Lychnis haageana) the symptoms of curly top were similar to those described on Maltese cross. 


\section{Ranunculaceae, Crowfoot Family}

Poppy anemone (Anemone coronaria) infected with curly top was stunted and chlorotic. The leaves were cupped downward (fig. 6) with petioles often twisted.

Love-in-a-mist (Nigella damascena) infected with curly top showed a marked stunting of the crown and developed dwarfed, yellow leaves, while the petioles of the older leaves were often curled downward (fig. 7 ).

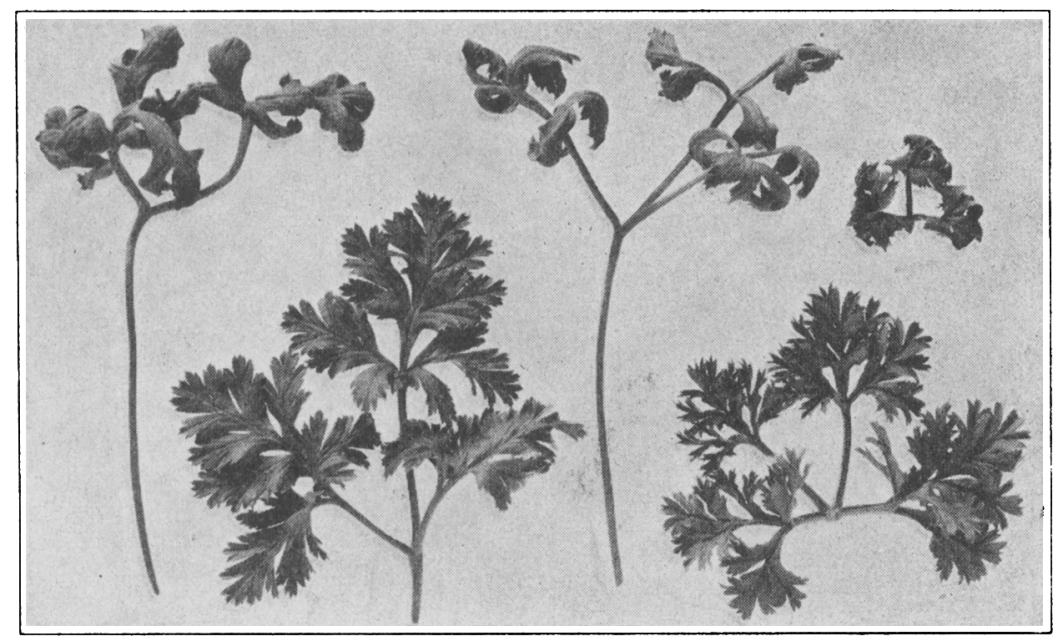

Fig. 6.-Poppy anemone (Anemone coronaria) : upper row, three leaves from a plant experimentally infected with curly top, showing downward-cupped leaves; lower row, two leaves from a healthy plant.

Older infected plants developed axillary shoots, which again developed secondary shoots forming a dense cluster. In the later stage of the disease, the plants were chlorotic.

Orange larkspur (Delphinium nudicaule) infected with curly top failed to develop symptoms of the disease under greenhouse conditions.

\section{Papaveraceae, Poppy Family}

Iceland poppy (Papaver nudicaule) infected with curly top had the youngest leaves dwarfed and either cupped inward or outward (plate $2, B)$. A yellow discoloration developed between the veins of the older leaves, while the area in the vicinity of the veins retained the green color for a long time (plate $2, B$ ).

The varieties of Oriental poppy (Papaver orientale) infected with curly top included an unnamed variety, the horticultural variety 


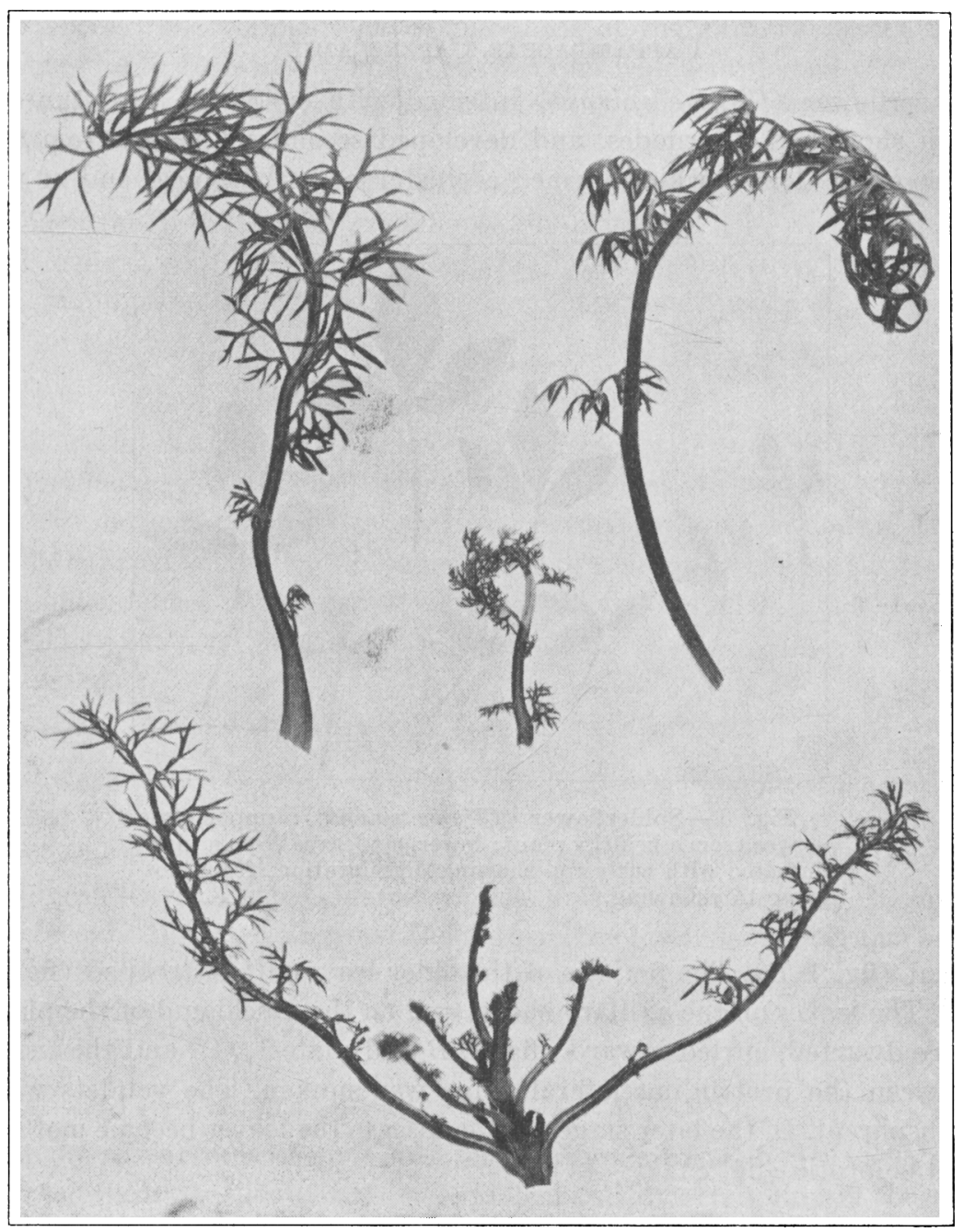

Fig. 7.-Love-in-a-mist (Nigella damascena) : upper, three leaves from a plant infected with curly top, showing crooked petioles; lower, terminal shoot, showing marked stunting of the crown and dwarfed leaves. 
Salmon Queen, and an Oriental poppy hybrid. All were stunted and chlorotic and had leaves cupped inward along the midrib.

\section{Capparidaceae, Caper Family}

Spiderflower (Cleome spinosa) infected with curly top was stunted, with shortened internodes, and developed secondary shoots from the axils of the leaves which formed a cluster near the apical end of the

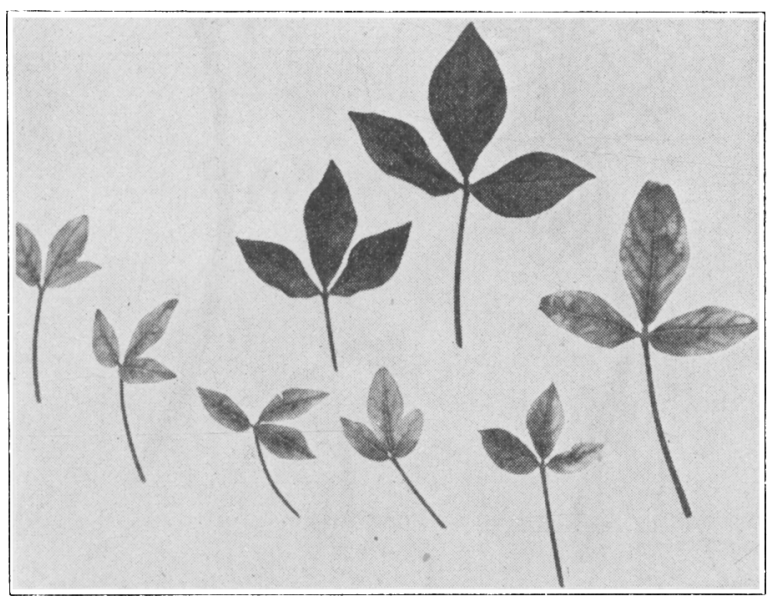

Fig. 8.-Spiderflower (Cleome spinosa): upper, two leaves from a healthy plant; lower, six leaves from a plant infected with curly top showing discoloration, from mottling to yellowing.

plant (fig. 4, B). The petioles of the older leaves often drooped (fig. 4, $B$ ). The leaves on the axillary shoots and on the apical end of the plant were dwarfed, curled inward (fig. $4, B$ and plate $1, C$ ), and the tissue between the protruding lateral veins was sunken. The veinlets were transparent. In the later stages of the disease the leaves became mottled and chlorotic (fig. 8).

\section{Cruciferae, Mustard Family}

On annual stock (Matthiola incana var. annua) the most conspicuous symptom of curly top was the light-brown exudations from the petioles and leaves, which later became dark brown in color. The plants were stunted and had shortened internodes and numerous axillary shoots bearing dwarfed leaves at the apical end of the plant. The lower leaves were dry and the upper older leaves thick and leathery. Young plants infected with curly top failed to develop flowers as they matured. 
Dames rocket (Hesperis matronalis), infected with curly top, was stunted and had numerous secondary shoots arising from the axils of the leaves. The younger leaves and those of the axillary shoots were dwarfed and formed a compact mass, from which projected the older, apparently normal leaves. The veinlets of the younger leaves were transparent.

Honesty (Lunaria annua) infected with curly top showed no symptoms of the disease under greenhouse conditions.

Purple candytuft (Iberis umbellata) infected with curly top showed no symptoms of the disease under greenhouse conditions.

\section{Resedaceae, Mignonette Family}

Common mignonette (Reseda odorata) infected with curly top developed numerous secondary shoots near the growing tips of the stems (fig. 5, $B$, p. 275), bearing dwarfed leaves curled downward, with sinuous margins and distorted veins. Protuberances were present on the lower surface of the older leaves. The inflorescence showed flowers with sepals, but no corollas (fig. 5, B) or with withered corollas.

\section{Geraniaceae, Geranium Family}

Fish geranium (Pelargonium hortorum), grown from cuttings and infected with curly top, was stunted and developed an inward rolling of the basal margin and an inward or outward cupping of the leaves. The youngest leaves showed cleared veinlets and protuberances on the lower surface. In the later stages of the disease, the lower leaves became chlorotic. Single giant-flowering hybrid geraniums grown from seeds infected with curly top developed symptoms similar to those on fish geranium.

\section{Tropaeolaceae, Tropaeolum Family}

Canary nasturtium (Tropaeolum peregrinum) infected with curly top, showed axillary shoots, twisted petioles, and dwarfed curled younger leaves (fig. 9). Near the terminal ends of the branches, the lobes of the older leaves were often curled.

\section{Euphorbiaceae, Spurge Family}

Snow-on-the-mountain (Euphorbia marginata) infected with curly top showed cleared veinlets on the younger, dwarfed, inward-cupped leaves (fig. 10). The older leaves were cupped outward and drooped from the stem, and in the later stages of the disease turned yellow. 


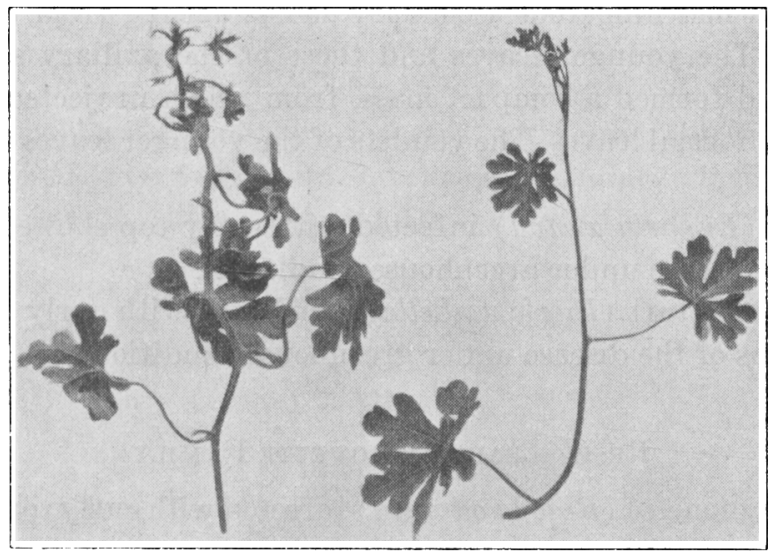

Fig. 9.-Canary nasturtium (Tropaeolum peregrinum) : left, apical shoot from a plant infected with curly top, showing small secondary shoots arising from the axils of the leaves; dwarfed, curled younger leaves; curled lobes of older leaves; and twisted petioles. Right, healthy check or control plant on which noninfective beet leafhoppers had fed.

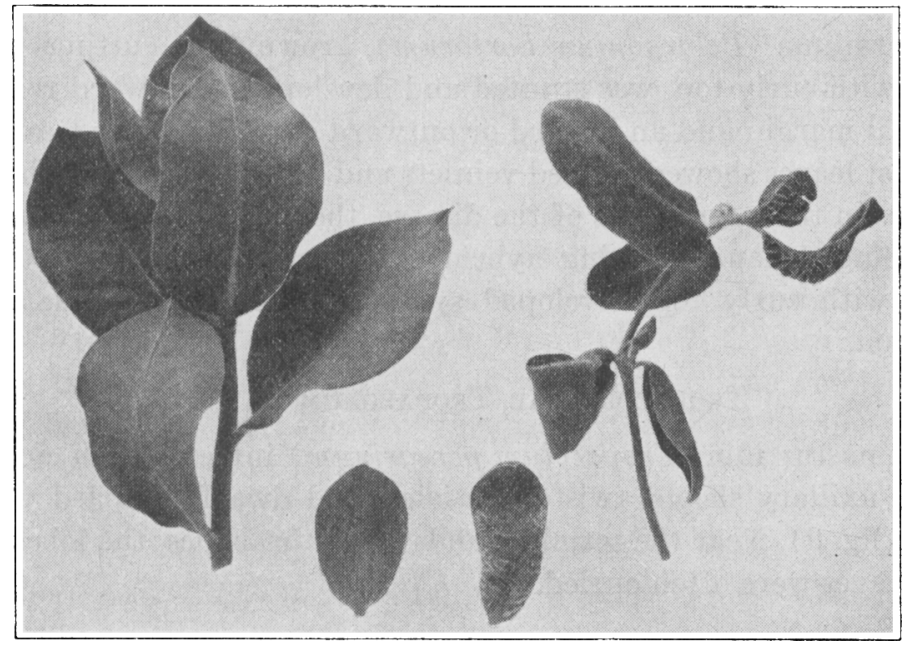

Fig. 10.-Snow-on-the-mountain (Euphorbia marginata): left, apical end of a branch from a healthy plant; right, apical end of a branch from a plant infected with curly top, showing cleared veinlets on the younger dwarfed, inward-cupped leaves. The older leaves are cupped outward and the lower leaves droop from the stem. 


\section{SAPINdACEae, Soapberry Family}

Balloonvine (Cardiospermum halicacabum) infected with curly top was stunted and developed secondary shoots from the axils of the leaves. Infected plants showed severe foliage symptoms. The leaves of the terminal,

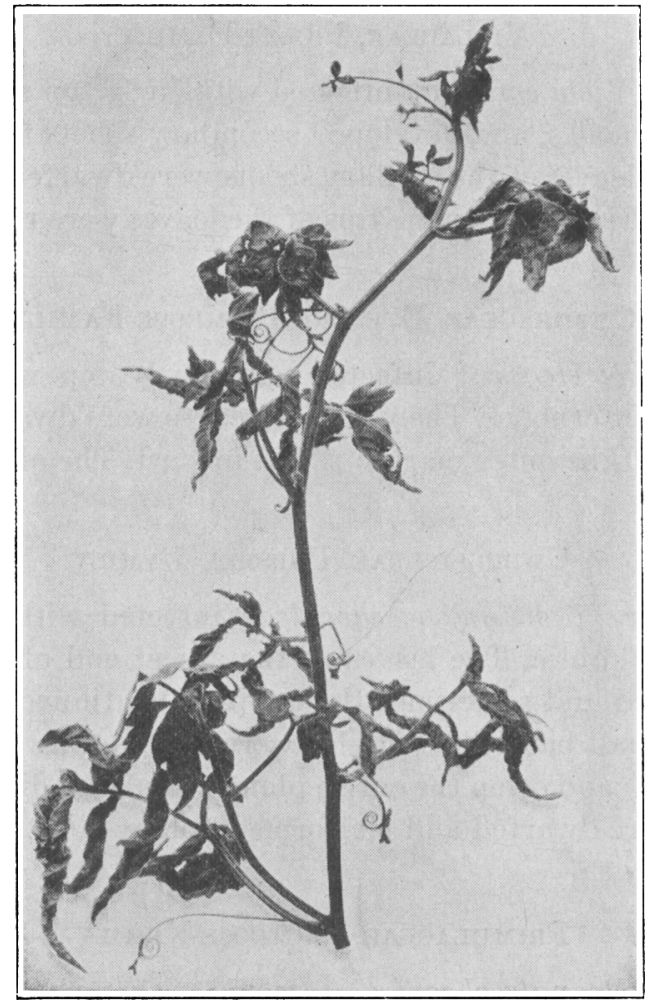

Fig. 11.-Balloonvine (Cardiospermum halicacabum ) : branch from a plant infected with curly top, showing severe foliage symptoms. The leaves of the terminal, lateral, and axillary shoots are dwarfed, curled, and twisted in clumps. The margins of the older leaves are rolled toward the midrib, with the tissue sunken between the lateral veins resulting in protruding veins.

lateral, and axillary shoots were dwarfed, curled, and twisted in clumps (fig. 11). The margin of the older leaves was rolled toward the midrib, and the tissue was sunken between the lateral veins, which resulted in protruding distorted veins (fig. 11). Wart-like protuberances were present on the lower surface of the leaves. 


\section{Malvaceae, Mallow Family}

Herb treemallow (Lavatera trimestris) infected with curly top was stunted, and developed outward-cupped leaves showing transparent venation. The plants were very susceptible to the disease and wilted and died prematurely.

\section{Violaceae, Violet Family}

Tufted pansy (Viola cornuta) infected with curly top was stunted, had shortened internodes, and developed secondary shoots from the axils of the leaves. The leaves of the axillary shoots were dwarfed and sometimes cupped along the midrib, or the tips of the leaves were rolled toward the midrib.

\section{Onagraceae, Evening-Primrose Family}

Clarkia (Clarkia elegans) infected with curly top was stunted and had shortened internodes. The youngest leaves were dwarfed, sometimes twisted, or with the outer margin rolled inward. The older leaves often drooped.

\section{Umbelliferae, Parsley Family}

Blue laceflower (Trachymene caerulea) infected with curly top was stunted and chlorotic. The leaves at the apical end of the plant were cupped outward and sometimes the cupping continued until each leaf resembled a small ball. The petioles were bent downward and became dry (plate $4, B$ ) and often the entire plant wilted and died prematurely. The flowers were dwarfed and malformed (plate $4, C$ ).

\section{Primulaceae, Primrose Family}

Top primrose (Primula obconica) infected with curly top was stunted. The youngest leaves were dwarfed, cupped outward, and chlorotic between the veins, while the area in the vicinity of the veins remained green. The veinlets were transparent.

Primula saxatalis infected with curly top was stunted, and the youngest leaves were cupped outward (fig. 12, $A$ ).

Cowslip primrose (Primula veris) infected with curly top was stunted and chlorotic.

Oxlip primrose (Primula elatior) infected with curly top was stunted and chlorotic, often wilted, and died prematurely. 


\section{Plumbaginaceae, Plumbago or Leadwort Family}

On notchleaf sea-lavender (Limonium sinuatum), the youngest leaves of infected plants were dwarfed and chlorotic.

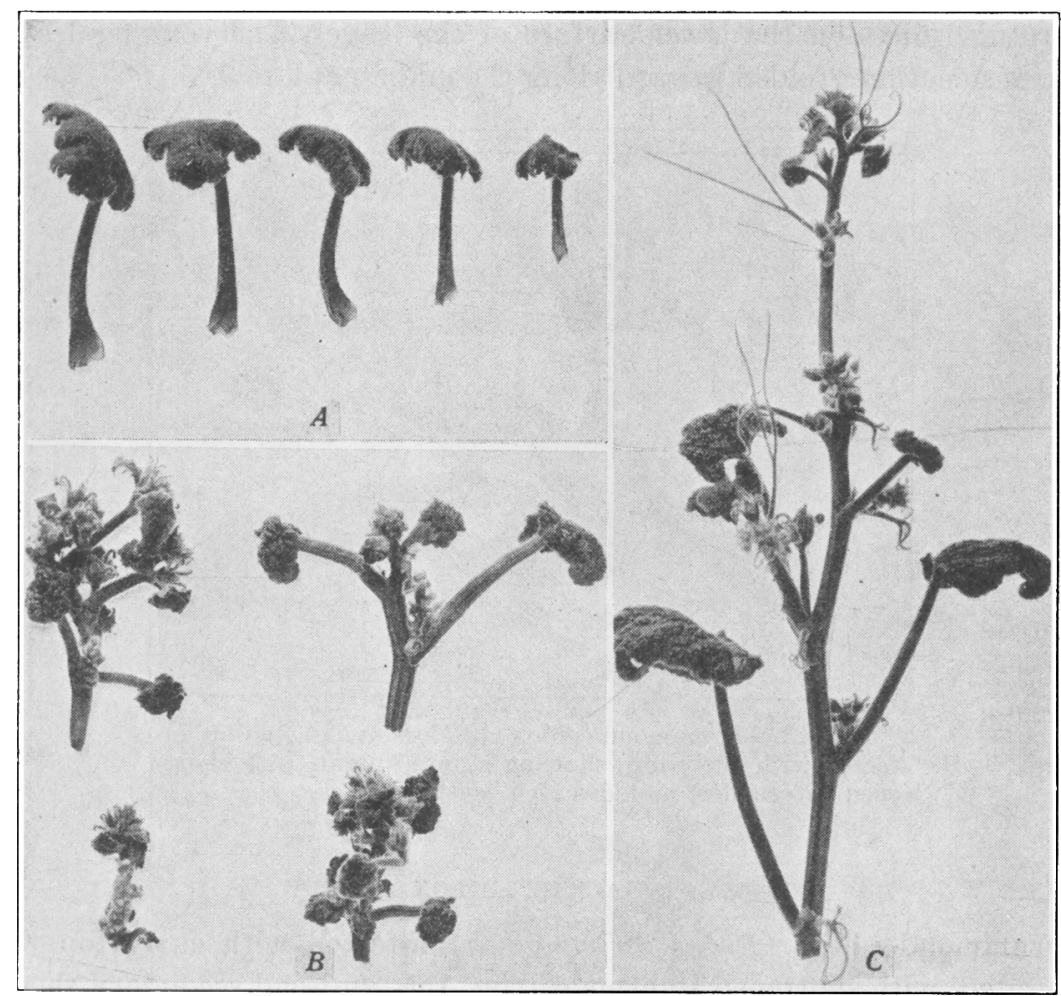

Fig. 12.-A, Primula saxatalis: leaves from a plant infected with curly top, showing outward-cupped leaves. B, Nest-egg gourd (Cucurbita pepo var. ovifera) : axillary shoots from an infected plant, showing dwarfed, puckered, balled leaves, with shortened petioles, and with dwarfed flowers. $C$, Spoon gourd (Lagonaria leucantha) : terminal shoot from an infected plant, showing outward-cupped leaves, and dwarfed tendrils.

\section{Apocynaceae, Dogbane Family}

Madagasear periwinkle (Vinca rosea) infected with curly top showed no symptoms under greenhouse conditions.

\section{Convolvulaceae, Morning-Glory Family}

Crimson starglory (Quamoclit lobata) infected with curly top showed an inward rolling of the margin of the older leaves with wart-like pro- 
tuberances on the lower surface (plate $2, C$ ). The younger leaves were twisted and developed bent petioles.

Brazilian morning-glory (Ipomoea setosa) infected with curly top showed an inward rolling of the margin of the older leaves, puckering of the blades, transparent venation (plate $3, A$ ), and sometimes wart-like protuberances on the lower surface of the leaves. The younger leaves were sometimes folded inward along the midrib (plate $3, A$ ).

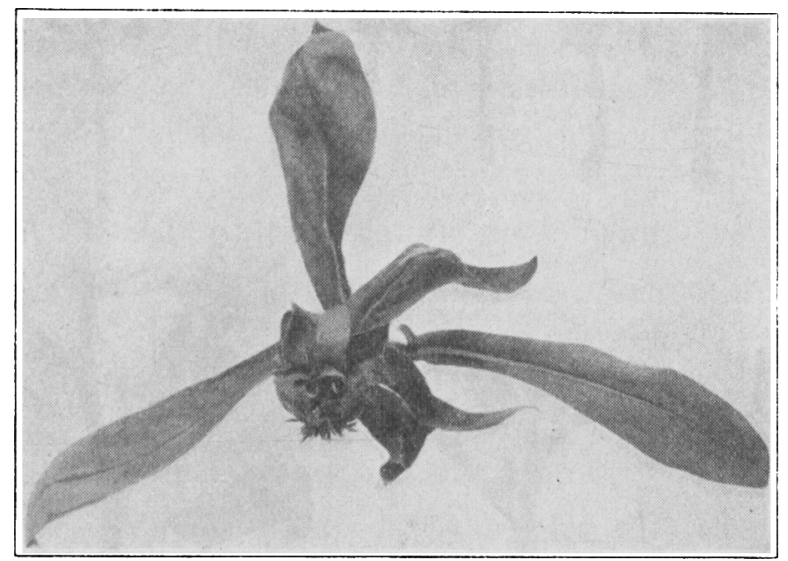

Fig. 13.-Drummond phlox (Phlox drummondii) infected with curly top, showing stunted plant, with shortened internodes, and dwarfed, curled leaves.

\section{Polemoniaceae, Phlox Family}

Drummond phlox (Phlox drummondii) infected with curly top was stunted, with shortened internodes (fig. 13), and had secondary shoots arising from the axils of the leaves. The leaves on the axillary shoots were dwarfed, linear near the tips, cupped inward, and chlorotic. The midrib of the older leaves was sinuous and the veinlets were transparent. The flowers near the apexes of the secondary shoots developed sepals but no petals.

On purplebell cobaea (Cobaea scandens) infected with curly top the apical leaflets were dwarfed and yellow, their protruding lateral veins resembled a corkscrew, and the petioles bent downward. The somewhat older leaves showed clear veinlets.

\section{Hydrophyllaceae, Water-leaf Family}

Spotted nemophila (Nemophila maculata) infected with curly top failed to show symptoms of the disease under greenhouse conditions. 


\section{Boraginaceae, Borage Family}

Alkanet (Anchusa azurea) infected with curly top was stunted. Its youngest leaves were dwarfed.

Chinese forget-me-not (Cynoglossum amabile) infected with curly top was stunted, had shortened internodes, and developed axillary shoots. The youngest leaves were dwarfed, curled, and twisted (fig. 14).

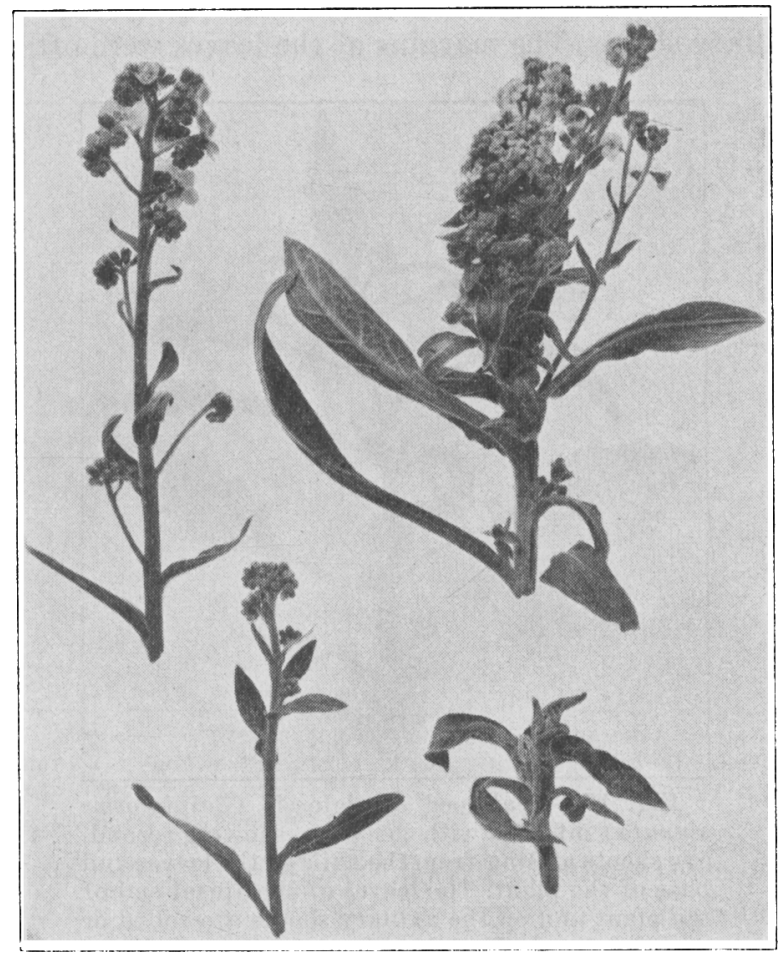

Fig. 14.-Chinese forget-me-not (Cynoglossum amabile) : left, terminal and lateral shoots from a healthy plant; upper right, flower stalks forming a dense cluster at the terminal end of a branch from an infected plant; lower right, lateral shoot, showing dwarfed, curled, and twisted leaves.

Brown droplets exuded from the leaves and stem. The flower stalks from numerous axillary shoots formed a dense cluster (fig. 14) and the flowers were frequently dwarfed and reduced in number.

True forget-me-not (Myosotis scorpioides) infected with curly top was stunted, and developed numerous secondary shoots. The youngest leaves were dwarfed, almost linear in shape near the apexes of the shoots, and chlorotic. The older leaves were curled downward with the 
margin cupped inward. The leaves on the secondary shoots were dwarfed and had a sinuous midrib and protuberances on the veins.

Common heliotrope (Heliotropium peruvianum) infected with curly top failed to show symptoms of the disease under greenhouse conditions.

\section{Labiatae, Mint Family}

Scarlet sage (Salvia splendens) infected with curly top and kept out of doors was stunted, had shortened internodes, and developed a compact mass of axillary shoots. The margins of the leaves were often rolled in-

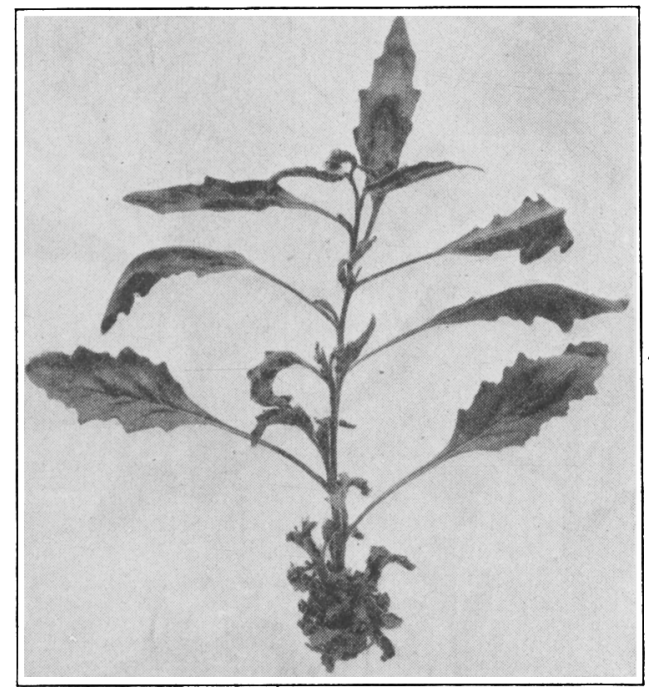

Fig. 15.-Scalloped salpiglossis (Salpiglossis sinuata) infected with curly top, showing secondary shoots arising from the axils of the leaves and base of the plant. The leaves of the apical end of the plant and on the axillary shoots are rolled or curled inward. The older leaves are cupped outward.

ward (plate $3, C$ ), or cupped inward along the midrib, the veinlets were transparent, and the petioles were bent downward. The leaves near the tips of the secondary shoots were dwarfed and chlorotic. The flowers were reduced in number, dwarfed, often failed to expand, and some remained green instead of the normal brilliant scarlet color.

Solanaceae, Nightshade Family

Jasmine tobacco (Nicotiana alata var. grandiflora) infected with curly top was stunted and had shortened internodes. The youngest leaves were dwarfed, cupped outward, and had cleared veinlets. 
Common petunia (Pctunia hybrida) (Rosy Morn variety) infected with curly top was stunted and developed numerous secondary shoots bearing dwarfed leaves. Protuberances were present on the veins on the lower surface of the leaves of the secondary and apical shoots and gave the veins a roughened appearance. The corolla of the flowers often failed to expand and became dry. In the later stages of the disease the entire plant turned yellow and died.

Scalloped salpiglossis (Salpiglossis sinuata) infected with curly top was stunted and had secondary shoots arising from the axils of the leaves

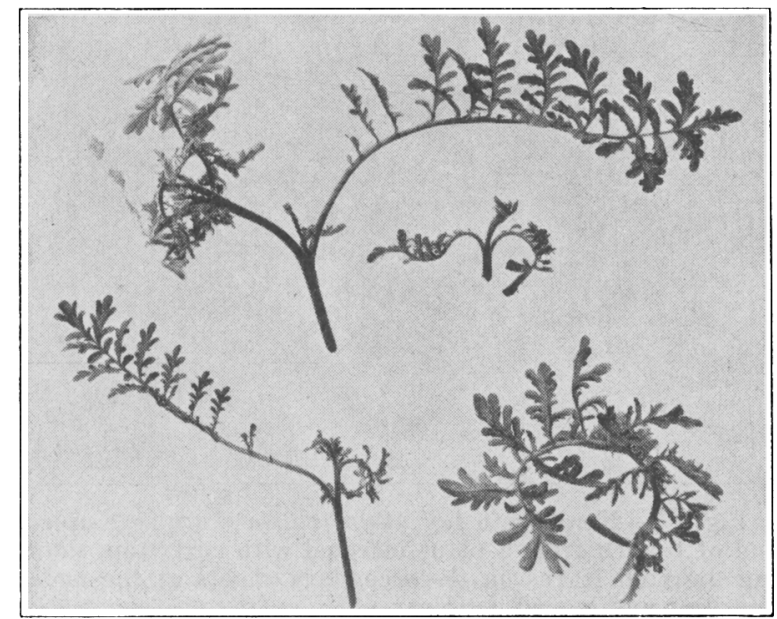

Fig. 16.-Wiseton butterflyflower (Schizanthus wisetonensis) : shoots and leaves from a plant infected with curly top, showing semicircular and eircular curling of the petioles of the younger leaves.

and base of the plant (fig. 15). The dwarfed, chlorotic leaves on the terminal end of the plant and on the axillary shoots were rolled or curled inward. The older leaves were cupped outward. The veinlets were transparent (plate $3, B$ ) and wart-like protuberances were present on the lower surface of the leaves.

On Browallia speciosa the terminal leaflets of infected plants were dwarfed, cupped inward along the midrib, and had protruding lateral veins. The veinlets were transparent at the base of the older leaves, and the petioles were bent downward.

Wiseton butterflyflower, Schizanthus wisetonensis (S. pinnatus $\times S$. grahami) infected with curly top showed a circular or semicircular curling of the petioles of the younger leaves (fig. 16). The leaves on the secondary shoots arising from the axils of the leaves were dwarfed and had curled petioles. Infected plants often wilted and died prematurely. 
Scrophulariaceae, Figwort Family

Yellow foxglove (Digitalis ambigua) infected with curly top developed youngest leaves which were dwarfed, cupped inward along the midrib, and the veinlets were transparent.

Kenilworth ivy (Cymbalaria muralis) infected with curly top developed a large number of dwarfed leaves on the secondary shoots at the

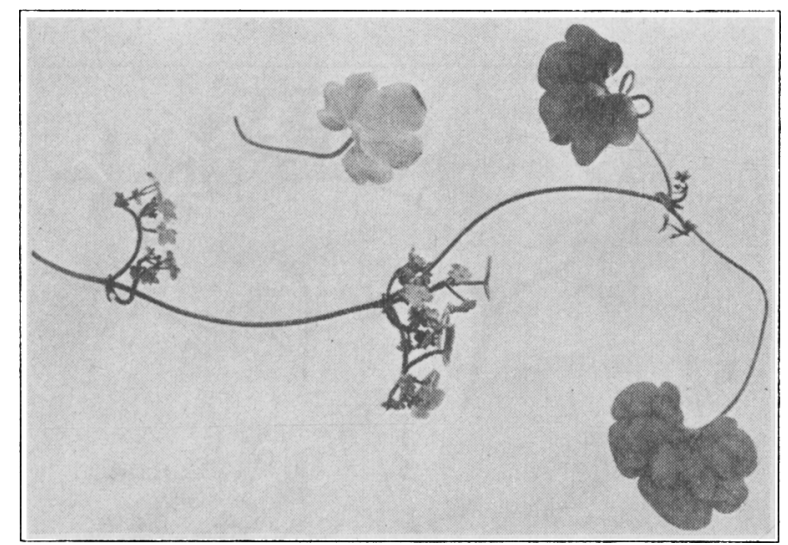

Fig. 17.-Kenilworth ivy (Cymbalaria muralis) : apical end of branch from a plant infected with curly top, showing dwarfed leaves on the secondary shoots at the nodes and bent and looped petioles.

nodes (fig. 17) instead of rooting at the nodes. The larger leaves at the apexes of the branches were slightly cupped inward with wart-like protuberances on the lower surface of the leaves and with bent or looped petioles (fig. 17).

Pouched nemesia (Nemesia strumosa) infected with curly top was stunted and chlorotic. The veinlets were transparent on the youngest leaves.

Golden monkeyflower (Mimulus luteus) infected with curly top failed to show symptoms of the disease under greenhouse conditions.

\section{Acanthaceae, Acanthus Family}

Black-eyed clockvine (Thunbergia alata) infected with curly top developed secondary shoots with dwarfed, puckered, yellow leaves (plate $2, A$ ). The veinlets were transparent (plate $4, E$ ). The petioles were often bent downward. 


\section{Cucurbitaceae, Gourd Family}

The ten ornamental gourds listed in table 2 were experimentally infected with curly top. The symptoms of curly top were the same on all ten. The plants were stunted and developed secondary shoots bearing chlorotic, dwarfed, puckered, outward-cupped leaves with shortened petioles (fig. $12, B$, p. 283). The leaves on the secondary shoots resembled a small ball.

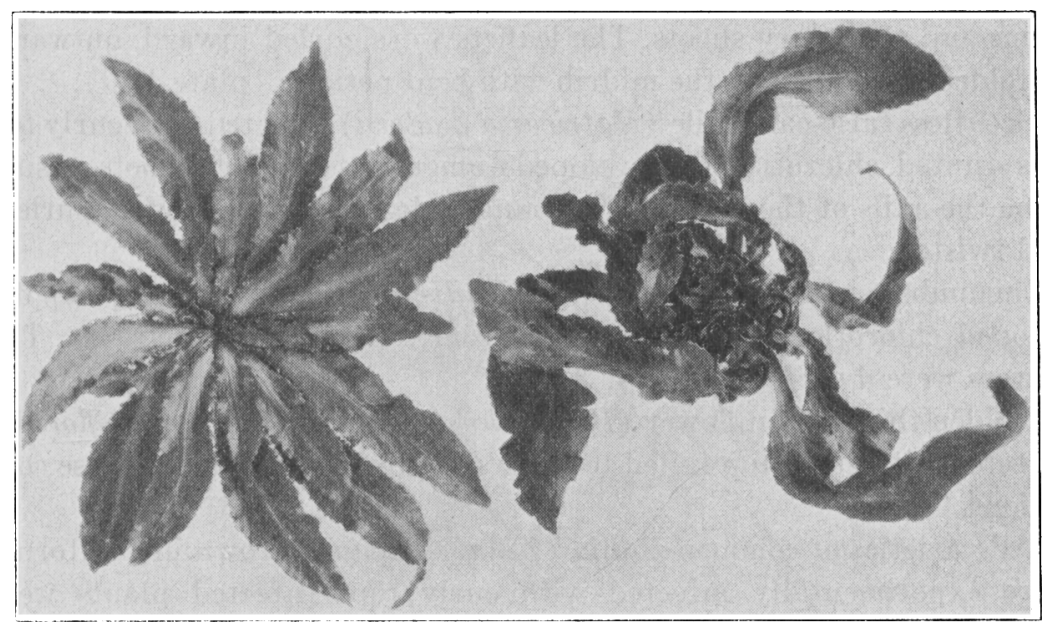

Fig. 18.-Cardinalflower (Lobelia cardinalis): left, healthy plant; right, plant infected with curly top, showing dwarfed, inward-curled young leaves and malformed, twisted, older leaves.

The older leaves were cupped outward (fig. 12, C), and dull green. The tendrills usually were dwarfed. The veinlets were transparent. The flowers in the axils of the leaves were sessile, and their corollas failed to expand and often withered prematurely.

\section{Lobeliaceae, Lobelia Family}

White-eye lobelia (Lobelia erinus var. speciosa) infected with curly top was stunted, and had numerous secondary shoots bearing dwarfed, chlorotic leaves.

Cardinalflower (Lobelia cardinalis) infected with curly top was stunted. The youngest leaves were dwarfed, puckered, with inwardcurled margins and cleared veinlets. The oldest leaves were malformed and twisted (fig. 18). 


\section{Compositae, Composite Family}

Crowndaisy (Chrysanthemum coronarium) infected with curly top was stunted, chlorotic, and had dwarfed, curled leaves.

Feverfew (Chrysanthemum parthenium) infected with curly top failed to show symptoms of the disease under greenhouse conditions.

Marguerite (Chrysanthemum frutescens) infected with curly top developed a dense cluster of dwarfed, chlorotic leaves at the apexes of the stems and secondary shoots. The leaflets were curled inward, outward, or folded inward along the midrib with bent petioles (plate $4, D$ ).

Scentless false-camomile (Matricaria inodora) infected with curly top was stunted, chlorotic, and developed numerous secondary shoots arising from the axils of the leaves. The youngest leaves were dwarfed, curled, and twisted.

Cucumber sunflower (Helianthus debilis) infected with curly top developed chlorotic, secondary shoots from the axils of the leaves. The flowers were dwarfed (plate $4, A$ ).

Golden thinleaf sunflower (Helianthus decapetalus var. multiflorus), infected with curly top failed to show symptoms under greenhouse conditions.

All varieties of common zinnia (Zinnia elegans) grown in California were experimentally infected with curly top. Infected plants were stunted, and had inward-cupped leaves showing cleared veinlets.

On orange zinnia (Zinnia haageana) the symptoms were similar to those described on common zinnia.

The cosmos varieties and species infected with curly top were common cosmos (Cosmos bipinnatus), giant-flowering cosmos (Cosmos bipinnatus) and crested cosmos (Cosmos hybridus). The symptoms on the three were similar. Infected plants were stunted, chlorotic, and had shortened internodes and secondary shoots arising from the axils of the leaves. The leaflets were curled and twisted with the petioles sometimes bent downward.

Calliopsis (Coreopsis tinctoria) infected with curly top developed secondary shoots with circular twisted leaves. The leaves on other portions of the plants showed no symptoms of the disease except drooping of the petioles. The terminal flower heads on the secondary shoots were dwarfed.

On English daisy (Bellis perennis) the youngest leaves infected with curly top were dwarfed, malformed, and cupped inward. The veinlets were transparent, and wart-like protuberances were present on the lower surface of the leaves. 
Swan-river-daisy (Brachycome iberidifolia) infected with curly top developed secondary shoots from the axils of the leaves terminating in tufts of dwarfed, twisted, yellow leaves (fig. 19). A tangled mass of leaves was present at the apical end of the plant and at the end of the stunted branches. The petioles of the older leaves were often curled downward, upward, or twisted.

Bushy arctotis (Arctotis stoechadifolia) infected with curly top de-

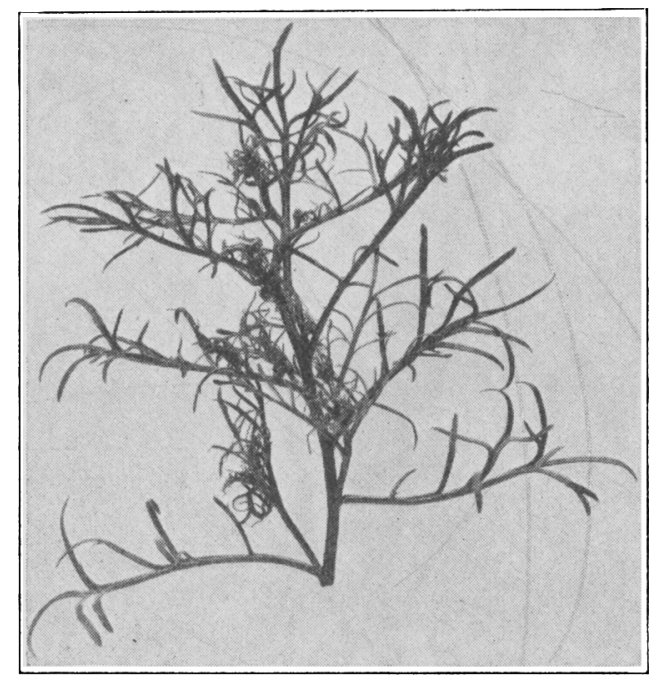

Fig. 19.-Swan-river-daisy (Brachycome iberidifolia): branch from a plant experimentally infected with curly top, showing secondary shoots arising from the axils of the leaves and terminating in a tuft of dwarfed, twisted leaves.

veloped leaves on the secondary shoots which were dwarfed and had the lobes curled inward.

French marigold (Tagetes patula) infected with curly top developed axillary shoots bearing dwarfed leaves with the petioles curled downward. The flower buds were yellow instead of green and the peduncles were often curled downward.

Aztec marigold, or African marigold (Tagetes erecta) infected with curly top failed to show symptoms under greenhouse conditions.

Winter cape-marigold (Dimorphotheca aurantiaca) infected with curly top was stunted, and developed shortened internodes and axillary shoots. In the advanced stage of the disease the terminal leaves were dwarfed, curled, and yellow (fig. 20). The teeth-like projections of the leaves were often curled inward. The longitudinal veins on the lower surface of the leaves were distorted. 
Pot-marigold (Calendula officinalis) infected with curly top failed to develop symptoms under greenhouse conditions.

Rose everlasting (Helipterum roseum) infected with curly top developed terminal shoots which were either erect or drooping with a cluster

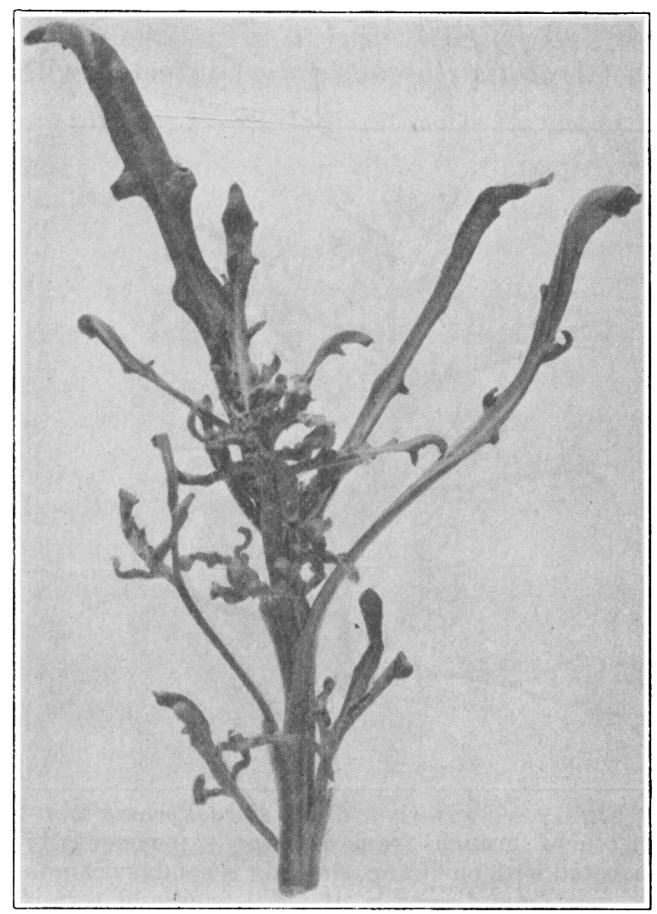

\footnotetext{
Fig. 20.-Winter cape-marigold (Dimorphotheca aurantiaca) : branch from a plant infected with curly top, showing dwarfed, curled leaves at the tip of the stem and also on the secondary shoots arising from the axils of the leaves. The teethlike projections of the leaves are often curled inward.
}

of twisted yellow leaves around the bud (fig. 21). The margin of the leaves below the bud were sinuous.

When small plants of strawflower (Helichrysum bracteatum) were infected with curly top they were stunted, their youngest leaves were dwarfed, twisted, and yellow in the advanced stage of the disease. The somewhat older leaves were also twisted and the veinlets were transparent. Plants infected at a later stage of development had numerous secondary shoots toward the tip of the branches with twisted leaves showing knot-like swellings on the veins. 
Sweet-sultan (Centaurca moschata) infected with curly top failed to develop symptoms of curly top under greenhouse conditions.

Basketflower (Centaurca americana) infected with curly top failed to show symptoms of the disease under greenhouse conditions.

On cornflower (Centaurea cyanus) infected with curly top, the leaves of the secondary shoots were dwarfed and sometimes two adjacent leaves were coiled downward.

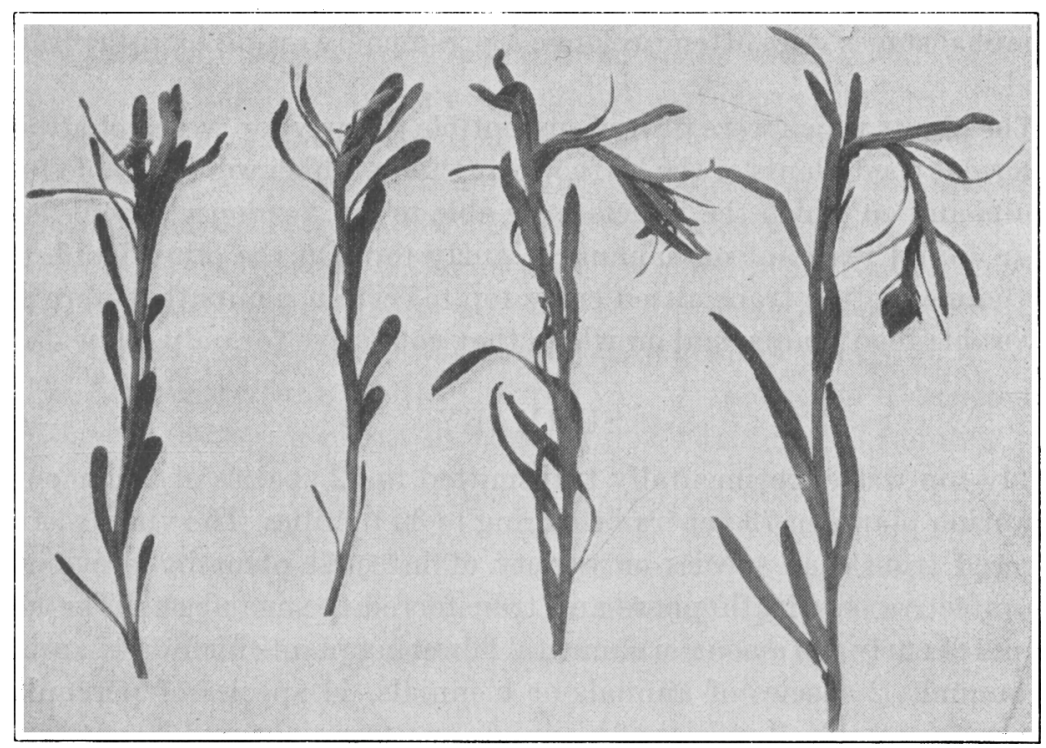

Fig. 21.-Rose everlasting (Helipterum roseum) : tips from plant infected with curly top, showing erect or drooping terminal shoots with clusters of twisted leaves around the buds.

\section{LONGEVITY AND LIFE CYCLE OF THE BEET LEAFHOPPER}

A comparative record was obtained of the longevity of male and female beet leafhoppers on plants on which the insects were not able to complete their life history. Adults of the spring or summer generations were used and not the dark adults of the overwintering generation. Two plants of each variety or species were inoculated with curly top by either male or female leafhoppers, and, by daily examination of each cage, a record was obtained of the longevity of the last living male and female as indicated in table 2. When the insects died after a short exposure on the host plant, presumably owing to unfavorable food, the plants were repeatedly inoculated by different lots of insects and the range in the longevity was determined. The longevity of the adults was often shorter on young plants than on older ones. 
A record was kept of all host plants on which the nymphs, after hatching from the egg, completed their nymphal stages and acquired the winged stage. The host plants of curly top on which the beet leafhopper completes its life cycle are indicated in table 2 . There was considerable variation in the percentage of specimens reared to the adult stage on the different host plants. This difference in population was probably due to the variation in the amount of suitable food provided by the plant.

On unfavorable food plants, the nymphs hatched but soon died. The nymphal stages were often prolonged, presumably owing to unfavorable food.

The plants which were proved susceptible to curly top were not always favorable food plants of the leafhopper. Plants which were suitable food plants and on which the insects were able to live for long periods were often found resistant or immune to curly top. On the other hand, the leafhoppers often transmitted curly top to certain plants that were unfavorable food plants, and on which they could live for only a few days.

\section{SUMMARY}

Curly top was experimentally transmitted to 92 species of ornamental flowering plants in 73 genera belonging to 33 families. The virus was recovered from each species or variety of infected plant by previously noninfective beet leafhoppers and transferred to sugar beets. The host plants of curly top among ornamental flowering plants include 47 species of annuals, 2 species of annuals or biennials, 11 species of perennials grown as annuals, 3 species of biennials or perennials, and 30 species of perennials.

Ornamental flowering plants infected with curly top show a variation in symptoms. Fifteen species, including 6 species of annuals, 2 species of annuals grown as perennials, and 7 species of perennials, failed to develop symptoms of the disease under greenhouse conditions.

Many of the plants infected with curly top were stunted and developed numerous secondary shoots from the axils of the leaves. Chlorosis and a development of shortened internodes was often characteristic of infected plants.

The leaves of some infected plants were dwarfed and often developed an inward rolling of the outer margin, and later the entire blade showed a pronounced inward curling toward the midrib. Other species showed an outward rolling of the leaves toward the midrib. In still other species the leaves may be cupped inward or outward, or they may be twisted, sometimes in a spiral. Puckering and mottling of the leaves occur in certain species and malformation of the leaves in others. 
Many infected ornamental flowering plants developed cleared veins, a reliable symptom of curly top on the sugar beet. Another reliable symptom of curly top is the roughened appearance on the lower surface of the leaves developing after the veinlets have cleared. The veins develop numerous small elevations resembling tiny warts. As the disease progresses, nipple-like papillae and knot-like swelling resembling galls develop here and there on the distorted, thickened veins.

Some infected plants, such as annual stock (Matthiola incana var. annua) and Chinese forget-me-not (Cynoglossum amabile) exude droplets of brown liquid from the veins, midrib, petioles, and stems.

Wilting and premature death of the plants occur with blue laceflower (Trachymene caerulea), Wiseton butterflyflower (Schizanthus wisetonensis), and herb treemallow (Lavatera trimestris).

Young plants infected with curly top frequently produce no flowers as they mature. Older plants infected before blooming often develop dwarfed, malformed, and fewer flowers than healthy plants.

The life cycle of the beet leafhopper was completed on 65 species of ornamental flowering plants in 51 genera, belonging to 23 families.

\section{ACKNOWLEDGMENTS}

Credit is due to Miss Katherine Jones, Division of Landscape Design, College of Agriculture, and Dr. H. L. Mason, Department of Botany, University of California, for the determination of some of the ornamental flowering plants. 


\section{LITERATURE CITED}

1 American Joint Committee on Horticultural Nomenclature.

1923. Standardized plant names. 546 p. J. Horace MeFarland Company, Harrisburg, $\mathrm{Pa}$.

2 BAILEY, L. H.

1914. Standard cyclopedia of horticulture. 6 vols. 3,639 p. The Macmillan Company, New York City.

${ }^{8}$ BAILEY, L. H.

1924. Manual of cultivated plants. 851 p. The Maemillan Company, New York City.

- Bailey, L. H., and E. Z. Bailey.

1930. Hortus. 652 p. The Macmillan Company, New York City.

${ }^{5}$ BaLd, J. G., and G. SAMUEL.

1931. Investigation on "spotted wilt" of tomatoes. Aust. Council Sci. and Indus. Research Bul. 54:1-24.

${ }^{6}$ Carsner, E.

1919. Susceptibility of various plants to curly top. Phytopathology 9:413-21.

${ }^{7}$ Freitag, J. H., and H. H. P. Severin.

1933. List of ornamental flowering plants experimentally infected with curly top. Plant Disease Reporter 17:2-5. [Issued by the U. S. Dept. Agr. Bur. Plant Indus.]

${ }^{8}$ GARDNER, M. W., and O. C. WHIPPle.

1934. Spotted wilt of tomatoes and its transmission by thrips. Phytopathology 24:1136.

${ }^{\circ}$ Gardner, M. W., C. M. Tompkins, and O. C. Whipple.

1935. Spotted wilt of truck crops and ornamental plants. Phytopathology 25:17.

${ }^{10}$ Grant, T. J.

1935. The host range and behavior of the ordinary tobacco-mosaic virus. Phytopathology 24:311-36.

11 KunkeL, L. O.

1926. Studies on aster yellows. Amer. Jour. Bot. 13:646-705. (Published also in Boyce Thompson Inst. Contrib. 1:181-240, 1926).

12 KUNKeL, L. O.

1931. Studies on aster yellows in some new host plants. Boyce Thompson Inst. Contrib. 3:85-123.

${ }^{13}$ McClean, A. P. D.

1935. Further investigations on bunch top disease of tomato. Union So. Africa Dept. Agr. Sci. Bul. 139:1-46.

${ }^{14}$ SEVERIN, H. H. P

1919. Investigations of the beet leafhopper Eutettix tenella Baker in California. Jour. Econ. Ent. 12:312-26.

15 Severin, H. H. P.

1919. The beet leafhopper. A report on investigations in California. Facts about Sugar 8:130-31, 134, 150-51, 170-71, 173, 190-91, 210-11, 250, 255. 
${ }^{16}$ Severin, H. H. P.

1921. Minimum incubation periods of causative agent of curly leaf in beet leafhopper and sugar beet. Phytopathology 11:424-29. Abstract in: Phytopathology 12:105.

${ }^{17}$ Severin, H. H. P.

1925. Percentage of curly top infection in beet leafhopper Eutettix tenellus (Baker) and winter host plants under field conditions. Jour. Econ. Ent. 18:733-37.

${ }^{18}$ Severin, H. H. P.

1927. Crops naturally infected with sugar beet curly top. Science 66:137-38.

${ }^{10}$ Severin, H. H. P.

1928. Transmission of tomato yellows or curly top of the sugar beet by Eutettix tenellus (Baker). Hilgardia 3(10):251-74.

${ }^{20}$ Severin, H. H. P.

1929. Additional host plants of curly top. Hilgardia 3(20):595-636.

${ }^{2}$ SEverin, H. H. P.

1929. Yellows disease of celery, lettuce, and other plants transmitted by Cicadula sexnotata (Fall.). Hilgardia 3(18) :543-82.

${ }^{22}$ SeVErin, H. H. P.

1929. Curly top symptoms on the sugar beet. California Agr. Exp. Sta. Bul. 465:1-35.

${ }^{23}$ Severin, H. H. P.

1931. Modes of curly-top transmission by the beet leafhopper, Eutettix tenellus (Baker). Hilgardia 6(8):253-76.

${ }^{24}$ SEVERIN, H. H. P.

1932. Transmission of carrot, parsley, and parsnip yellows by Cicadula divisa. Hilgardia 7(3):163-79.

${ }^{25}$ SeVterin, H. H. P.

1934. Weed host range and overwintering of curly top virus. Hilgardia 8(8): 263-80.

${ }^{20}$ Severin, H. H. P., and J. H. Freitag.

1933. List of ornamental flowering plants naturally infected with curly top or yellows diseases in California. Plant Disease Reporter 17:1-2 [Issued by U. S. Dept. Agr. Bur. Plant Indus.]

${ }^{27}$ Severin, H. H. P., and J. H. Freitag.

1934. Ornamental flowering plants naturally infected with curly-top and aster-yellows viruses. Hilgardia 8(8):233-60.

28 Severin, H. H. P., and C. F. Henderson.

1928. Some host plants of curly top. Hilgardia $3(18): 339-92$.

${ }^{20}$ SмIтH, K. M.

1931. Studies on potato virus diseases. VIII. On a ringspot virus affecting solanaceous plants. Ann. Appl. Biol. 18:1-15.

${ }^{30}$ SмIтH, K. M.

1931. Thrips tabaci Lind. as a vector of plant virus disease. Nature (London) $127(3214)$ : 852-53. 
${ }^{31}$ SмITH, K. M.

1932. Studies on plant virus diseases. XI. Further experiments with a ringspot virus: its identification with spotted wilt of the tomato. Ann. Appl. Biol. 19:305-30.

32 Tompkins, C. M., and M. W. Gardner.

1934. Spotted wilt of head lettuce. Phytopathology 24:1135.

${ }^{33}$. WeLlman, F. L.

1934. Identification of celery virus $I$. The cause of southern celery mosaic. Phytopathology 24:695-725.

${ }^{34}$ Wellman, F. L.

1935. The host range of the southern celery mosaic virus. Phytopathology 25:377-404.

${ }^{35}$ Wingard, S. A.

1928. Host and symptoms of ringspot, a virus disease of plants. Jour. Agr. Research 37:127-53.

${ }^{36}$ Wingard, S. A., and J. Godkin.

1924. Tobaceo diseases in Virginia and their control. Virginia Agr. Ext. Bul. $90: 1-31$. 


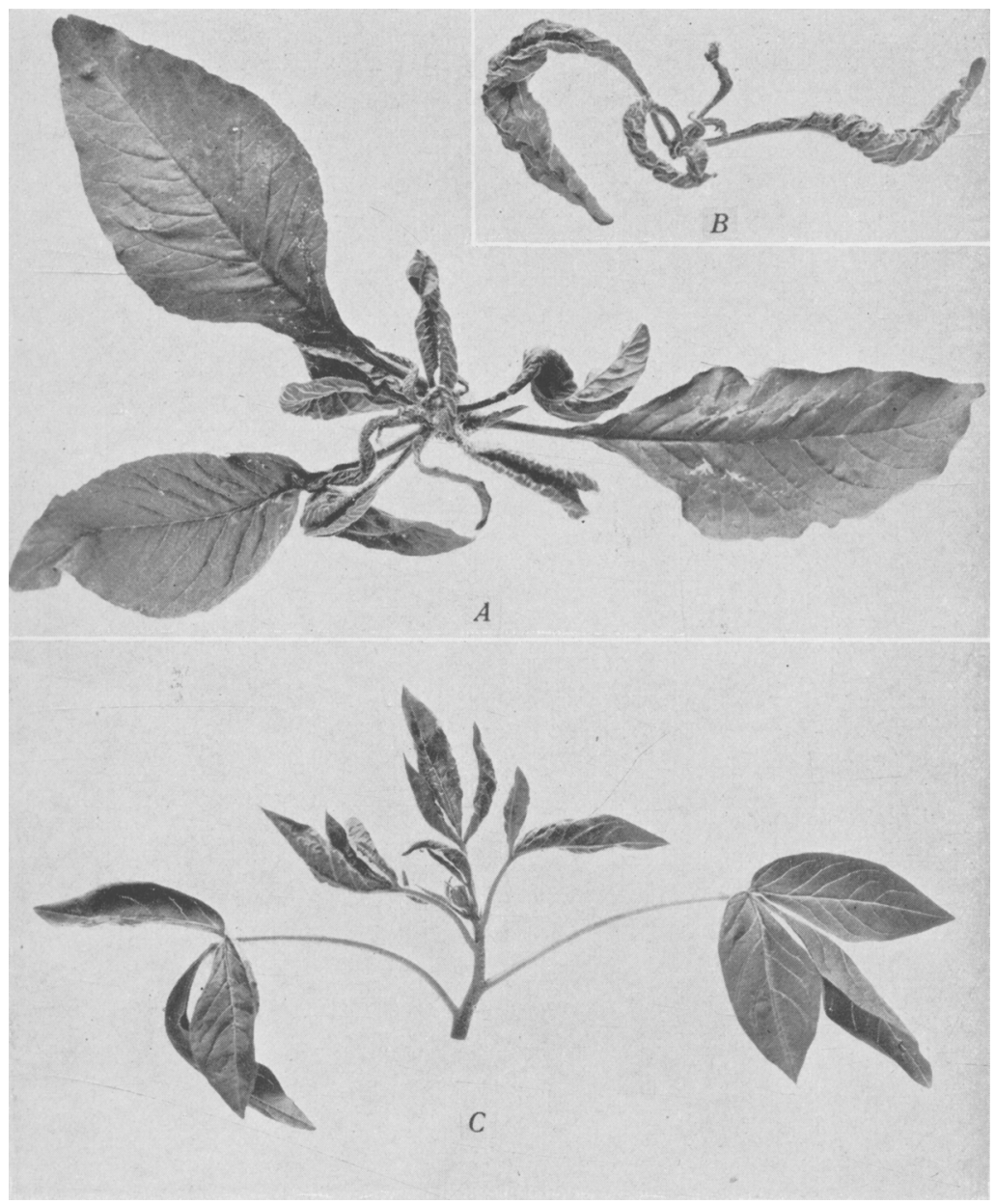

Plate 1.-A, Terminal shoot of Amaranthus aurora infected with curly top, showing dwarfed, terminal leaves with the outer margin rolled inward and with the petioles bent downward or twisted. $B$, Terminal shoot of Josephs-coat (Amaranthus gangeticus) with the tissue sunken between the lateral veins and with protuding veins resembling a corkscrew. $C$, Terminal shoot of spiderflower (Cleome spinosa) infected with curly top, showing dwarfed, inward-curled leaflets. 


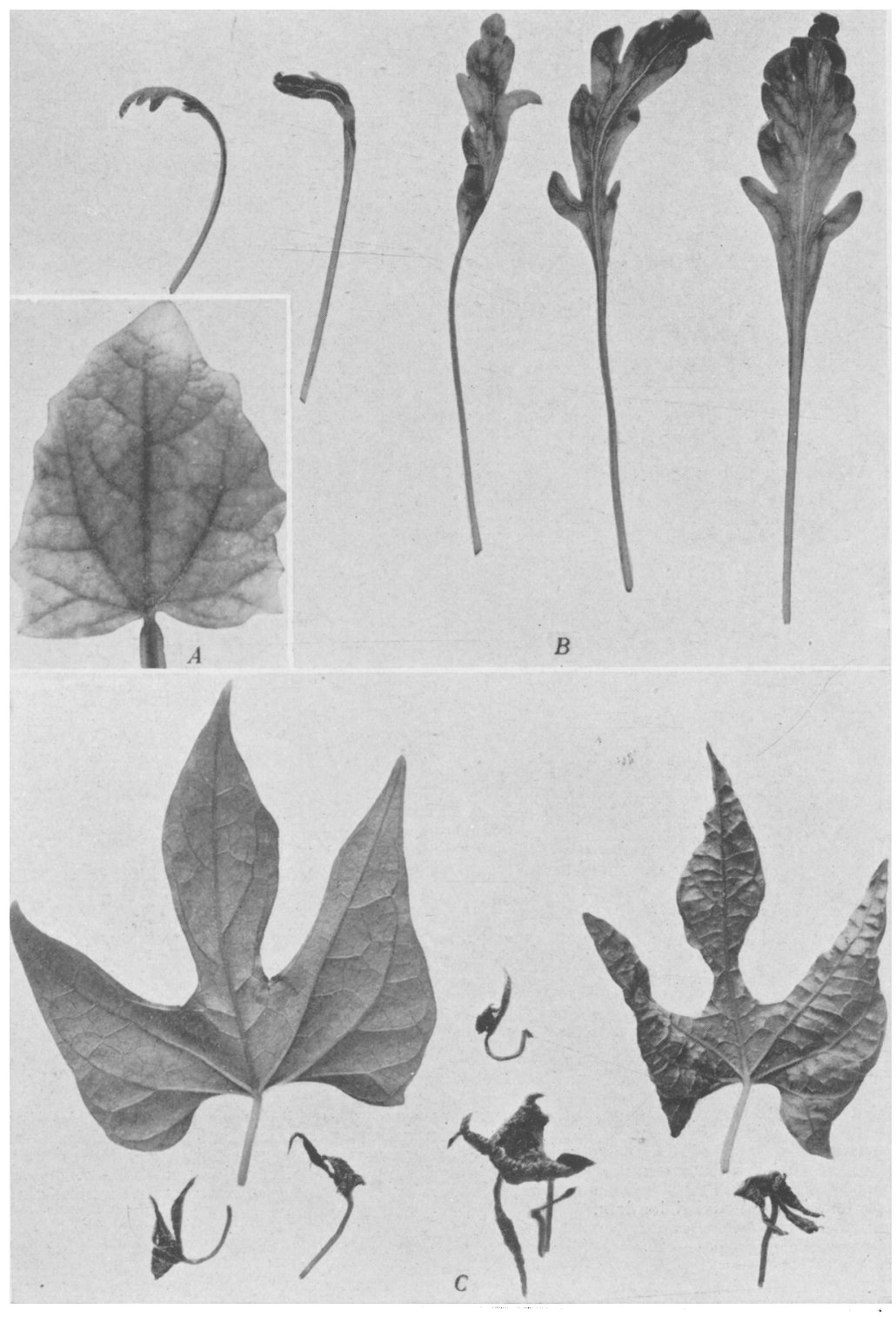

Plate 2.-A, Black-eyed clockvine (Thunbergia alata): chlorotic leaf from a plant infected with curly top. $B$, Iceland poppy (Papaver nudicaule) : left, two small leaves from an infected plant showing outward and inward cupping; right, three leaves showing successive stages of yellowing between the veins, while the area along the veins remained green for a long time. $C$, Crimson starglory (Quamoclit lobata): left, large leaf from a healthy plant used as a check or control on which noninfective beet leafhoppers had fed right, large leaf from a plant infected with curly top showing protuberances on the lower surface; small leaves showing malformations. 


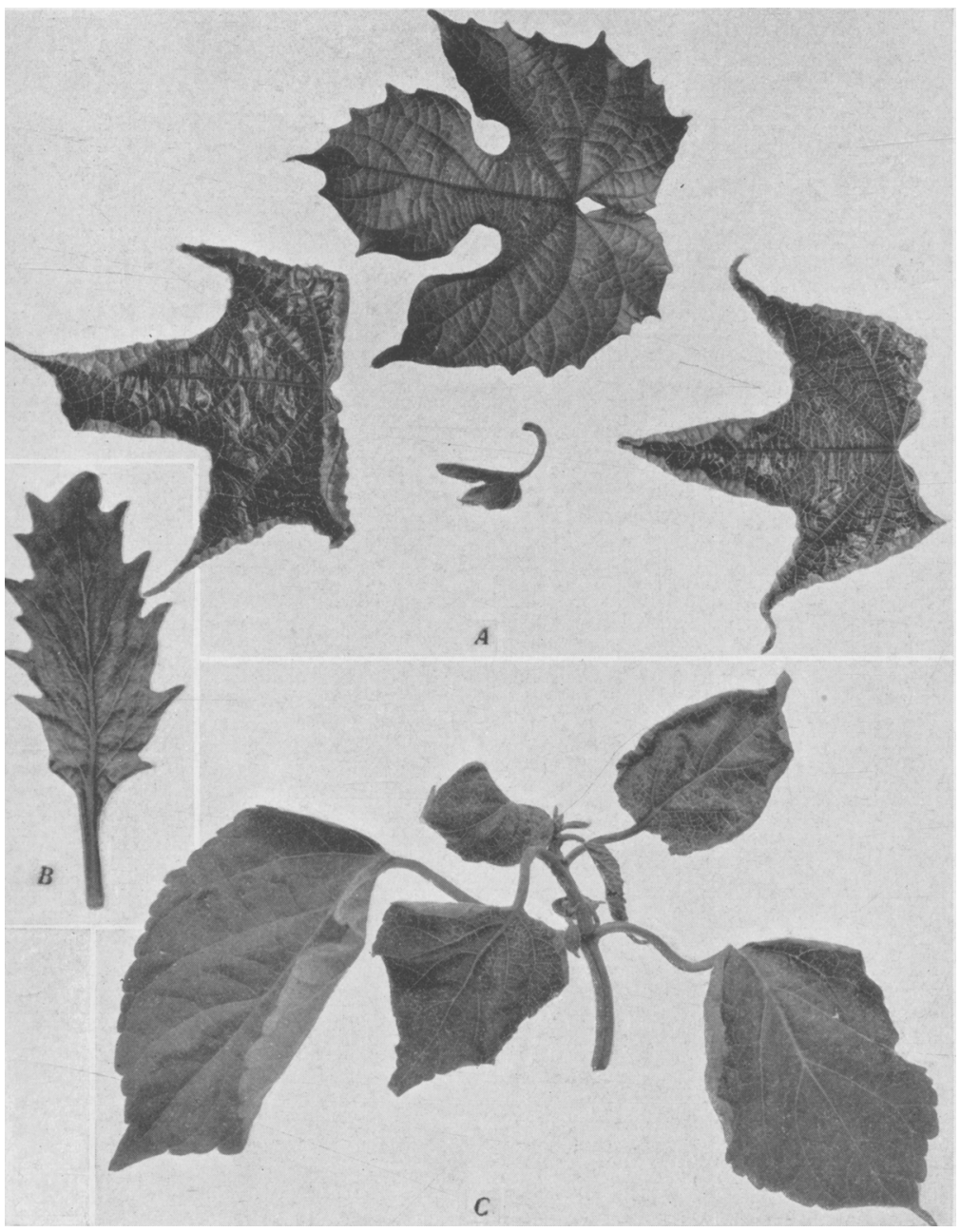

Plate 3.-A, Brazilian morning-glory (Ipomoea setosa): right and left leaves, from a plant infected with curly top showing inward rolling of the margin and transparent venation; lower center, leaf folded inward along the midrib; upper center, leaf from a healthy plant used as a check or control on which noninfective beet leafhoppers had fed. $B$, Scalloped salpiglossis (Salpiglossis sinuata) : leaf showing cleared veinlets. $C$, Scarlet sage (Salvia splendens): apical shoot from a plant infected with curly top showing in ward roll of the margin of the youngest leaves, cleared veinlets, and bent petioles. 

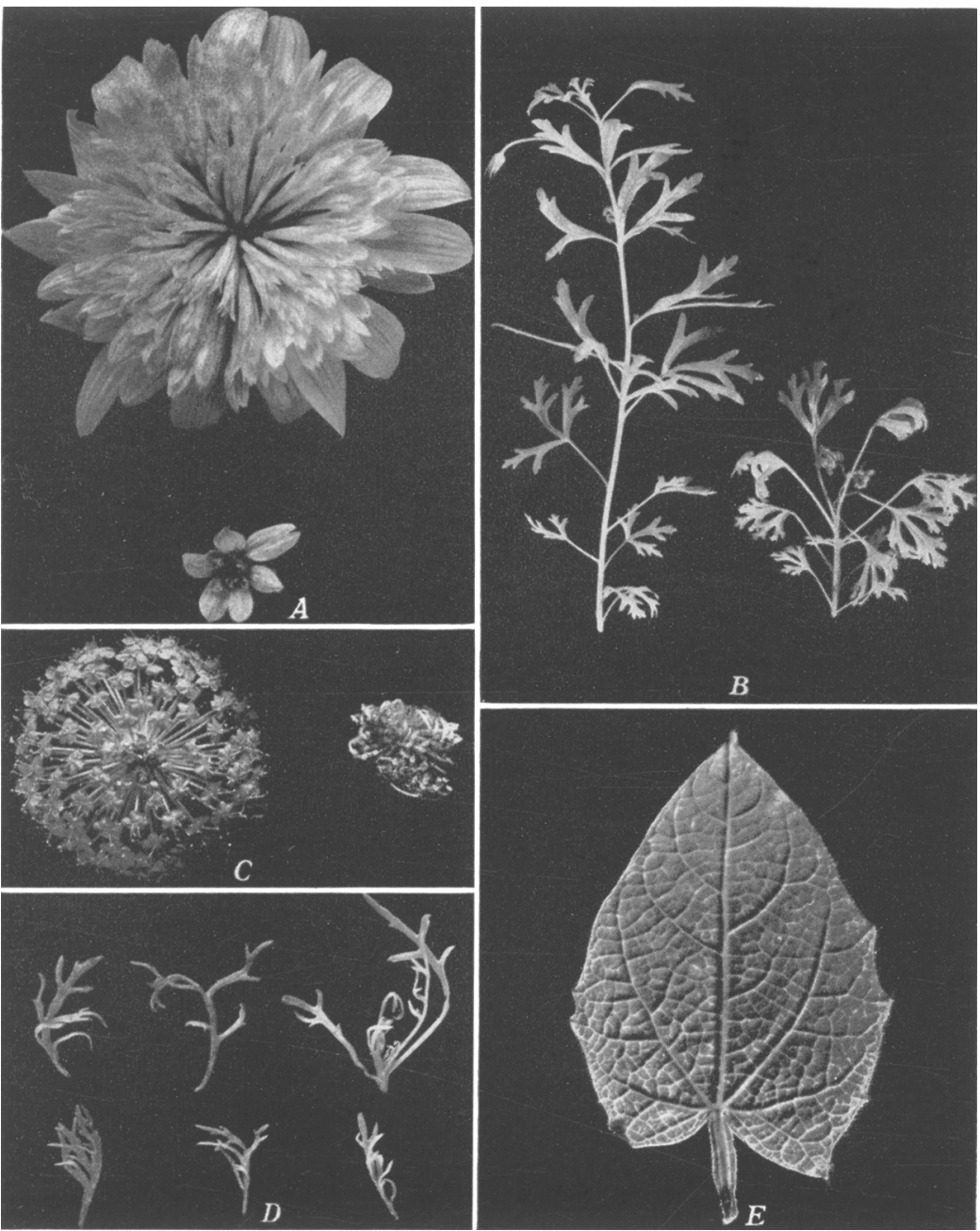

Plate 4.-A, Cucumber sunflower (Helianthus debilis): upper, flower from a healthy plant; lower, dwarfed flower from a plant infected with curly top. $B$, Blue laceflower (Trachymene caerulea) : left, healthy plant which had been exposed to noninfective beet leafhoppers; right, stunted plant infected with curly top by infective beet leafhoppers showing outward-cupped leaves and dried petioles. $C$, Blue laceflower (Trachymene caerulea): left, normal flower from a healthy plant; right, $\mathrm{dwarfed}$ and malformed flower from an infected plant. D, Marguerite (Chrysanthemum frutescens): secondary shoots and leaves from a plant infected with curly top, showing curled leaflets. $E$, Black-eyed clockvine (Thunbergia alata): leaf from a plant infected with curly top showing cleared veinlets. 